Journal of Social Sciences (COES\&RJ-JSS)

ISSN (E): 2305-9249 ISSN (P): 2305-9494

Publisher: Centre of Excellence for Scientific \& Research Journalism, COES\&RJ LLC

Online Publication Date: 1st October 2018

Online Issue: Volume 7, Number 4, October 2018

https://doi.org/10.25255/jss.2018.7.4.303.335

\title{
The Effect of Strategic Management of Regulatory Factors on Administrative Decision: An Analytical Study on Jordanian Phosphate Company
}

\author{
Tagreed Kattoua \\ Lecturer of Business Management, Al-Balqa Applied University, \\ Princess Alia University College, Jordan \\ taghreedkattoua@gmail.com \\ Musa Al-Lozi \\ Department of Public Administration, School of Business, \\ The University of Jordan, Amman, Jordan \& President of Aqaba Branch, \\ The University of Jordan, Aqaba, Lozi.musa@ju.edu.jo \\ Ra'ed Masa'deh \\ Department of Management Information Systems, School of Business, \\ The University of Jordan, Amman, Jordan, r.masadeh@ju.edu.jo
}

\begin{abstract}
:
This research shed lights on the strategic impact of the regulatory factors on the administrative decision in the period from 2006 to 2016 - an applied study on Jordan Phosphate Company. The study focused mainly on observations and questionnaire. The questionnaire included personal data and statements dealing with organizational factors and administrative decision. The most important results are: The regulations and instructions helped to develop the administrative decision of Jordan Phosphate Company, and the process of administrative authorization within the Jordan Phosphate Company helped to achieve efficiency and good performance. In the light of the results, a number of recommendations were made, including: the need to take into account the internal and external factors so as not to adversely affect the process of administrative decision-making, the use of experts in the field of administrative decision-making to solve problems in the Jordanian Phosphate Company and raise the efficiency of performance, besides the attention to remove the obstacles that limit the participation of employees in Jordan Phosphate in administrative decision-making.
\end{abstract}

Keywords:

Strategic Management, Regulatory Factors, Administrative Decision, Phosphate Company, Jordan

\section{Citation:}

Kattona, Tagreed; Al-Lozi, Musa; Masa'deh, Ra'ed (2018); The Effect of Strategic Management of Regulatory Factors on Administrative Decision: An Analytical Study on Jordanian Phosphate Company; Journal of Social Sciences (COES\&RJ-JSS), Vol.7, No.4, pp:303-335; https://doi.org/10.25255/jss.2018.7.4.303.335.

This work is licensed under a Creative Commons Attribution 4.0 International License. 


\section{أثر الإدارة الإستراتيجية للعوامل التظيمية على القرار الإداري: دراسة تحليلية على شركة

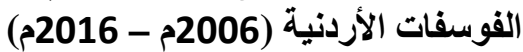

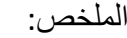

يتناول هذا البحث الأثر الاستر اتيجي للعوامل التنظيمية على القرار الإداري في الفترة من 2006م- 2016م - دراسة

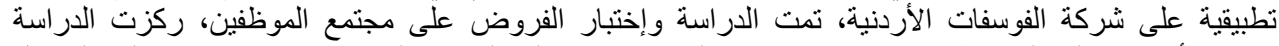

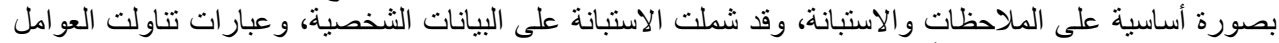

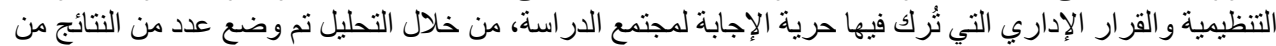

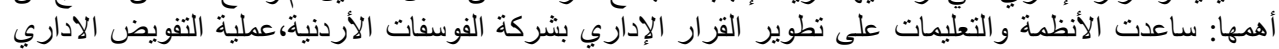

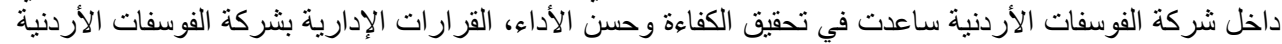

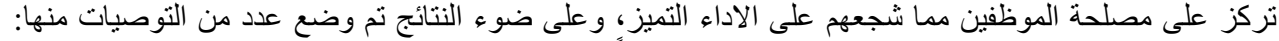

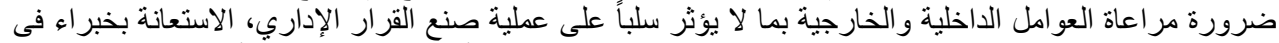

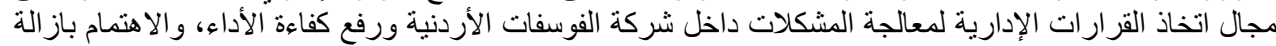

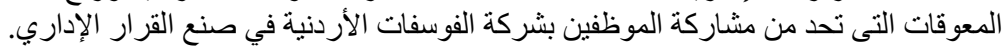

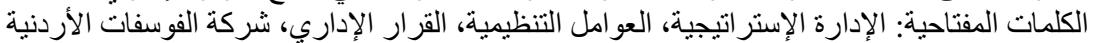

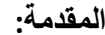

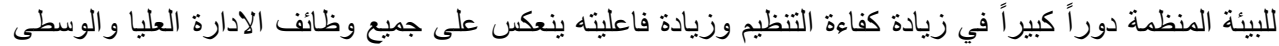

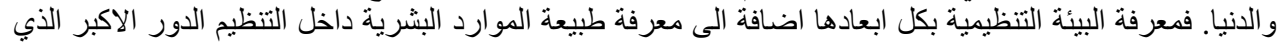

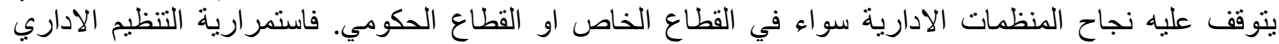

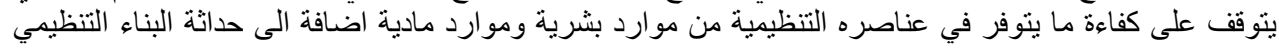
وقدرته على التكيف مع البيئة الخارجية وما تمثلكه من تحديات

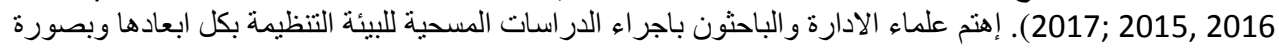

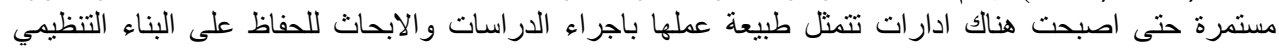

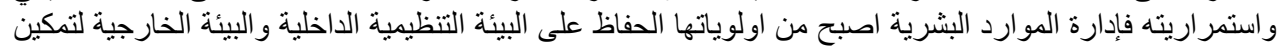

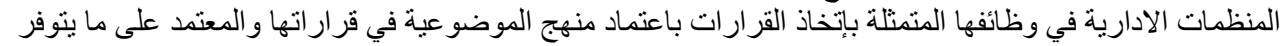

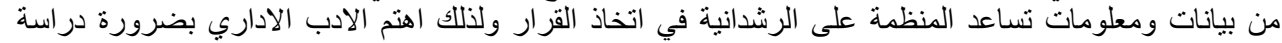

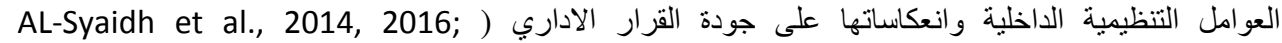
الإدة (Darawsheh et al., 2016; Masa'deh et al., 2015;

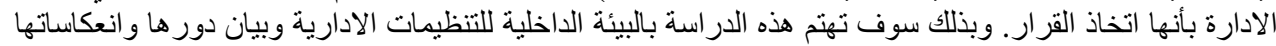

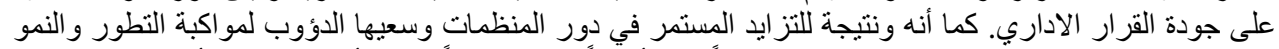

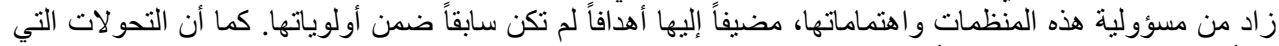

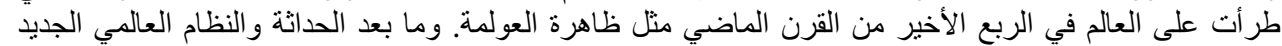

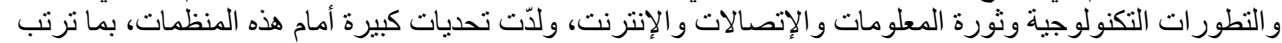

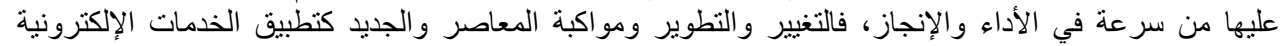
كخدمات الحكومة الإلكترونية ونظم ادارة المعرفة أصبح يمثل روح أيّ تطور أو تغيير نحو الأفضل ( Tarhini et al., 2015; AlHrassi et al., 2016; Almajali et al., 2016; Masa'deh et al., 2018; Yassien \& Mufleh, 2017; Alenezi et al., 2017; Alkandari et al., 2017; Khwaldeh et al., 2017; Mikkawi

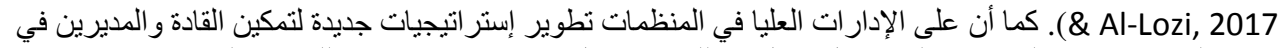

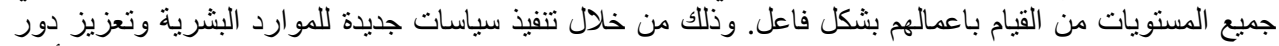

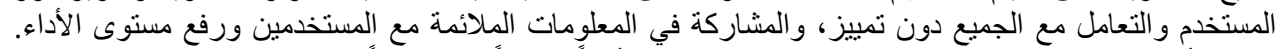

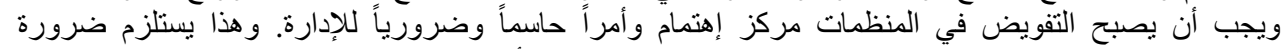

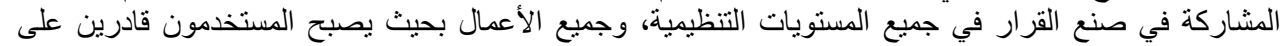

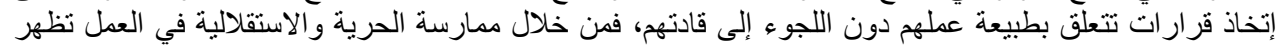


The Effect of strategic management.....

AL-Lozi, 2002; Arnold \& Pulich, 2003; Ammari et al., ) نتائج الأداء بصورة جيدة من حيث النوعية .(2017; Obeidat et al., 2017; Abualoush et al., 2018

مثكلة البحث

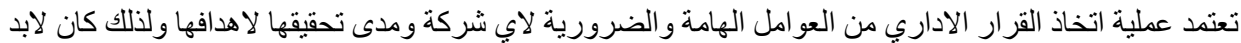

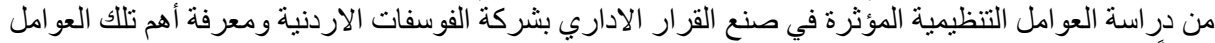

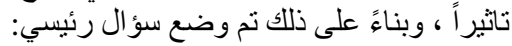

ما هو الاثر الاستراتيجي للعو امل التنظيمية على صنع القرار الإداري بشركة الفوسفات الأردنية؟ ومنها تفر عت الأسئلة التالية:

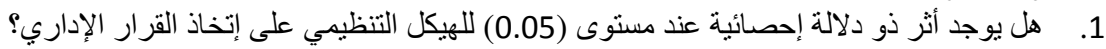

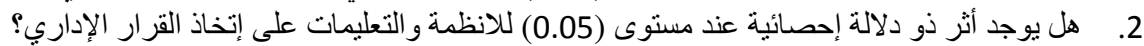

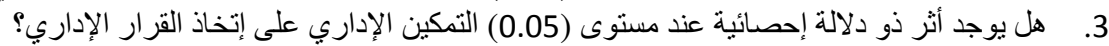

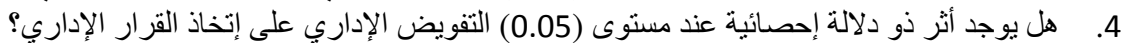

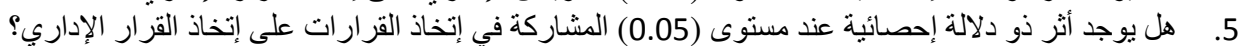

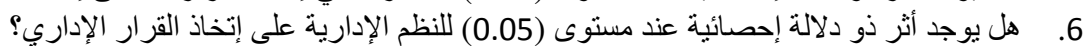

7.

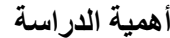

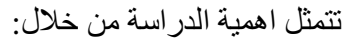

توفر مرجع للار اسة اثر العوامل التنظيمية على القرار الاداري.

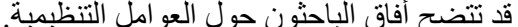

3

4.

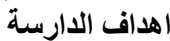

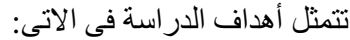

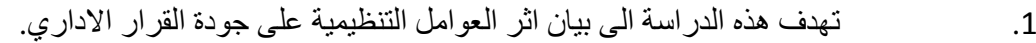

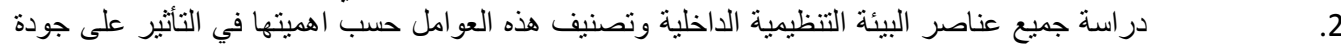

القرار الاداري.

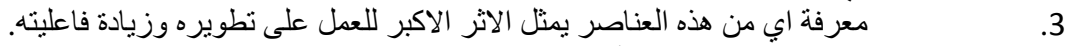

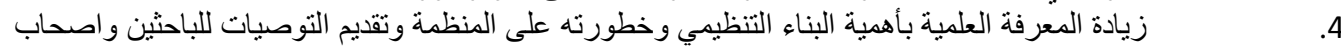

فرضيات الاراسة البحت

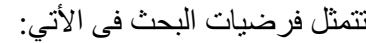

1. يوجد أثر ذو دلالة إحصائية عند مستوى (0.05) للهيكل التنظيمى على إنخاذ القرار الإداري.

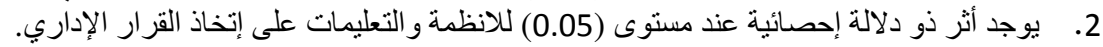

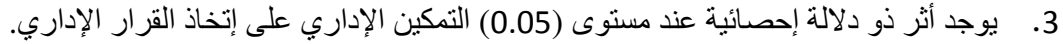

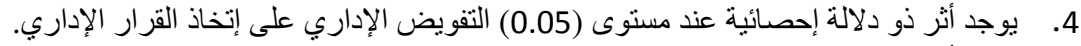

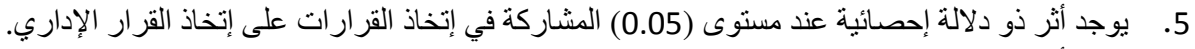

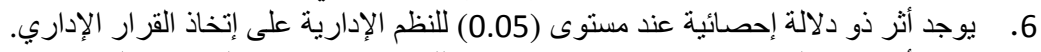

7. يوجد أثر ذو دلالة إحصائية عند مستوى (0.05) للقرارات الإدارية على إنخاذ التخاذ القرار الإداري.

اعتمدت هذه الدر اسة على المنهج الوصفي والتاريخي نسبة ملائمة هذه المناهج لطبيعة الدراسة الحالية. 


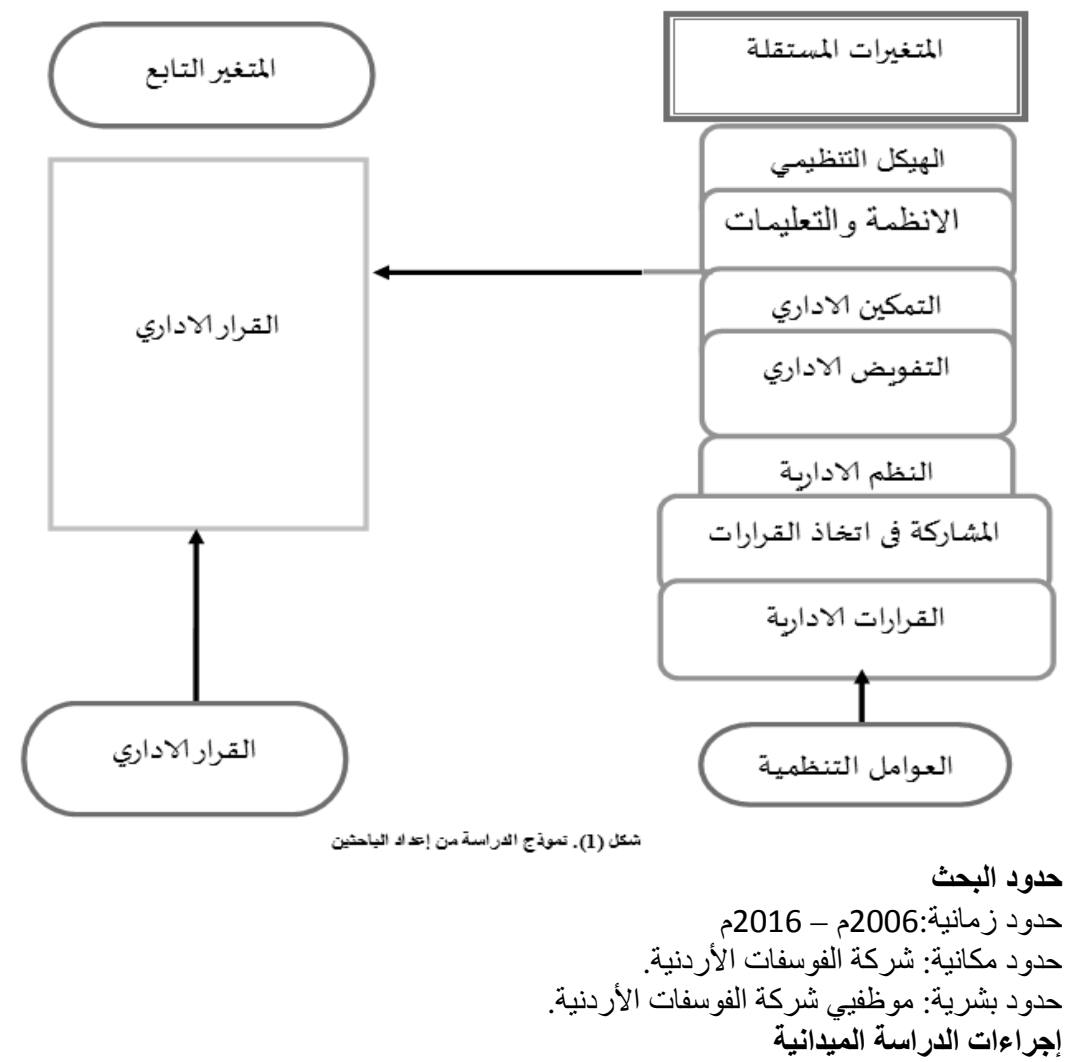

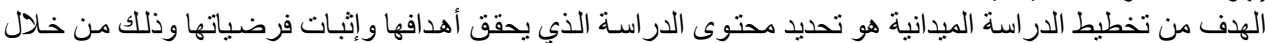

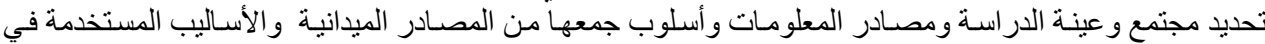

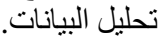

أولاً: مجتمع الاراسة الثة

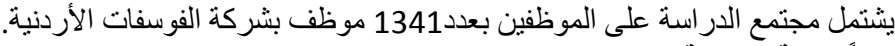
ثانياً: عينة الدراسة الإنة

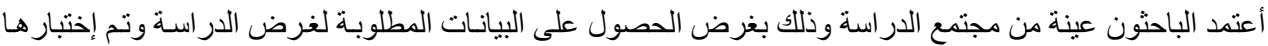

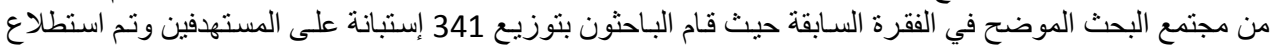

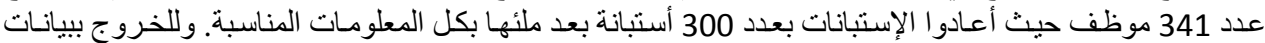

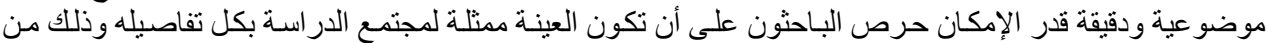
حيث شمولها على الخصائص التالية:

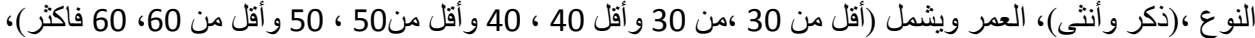

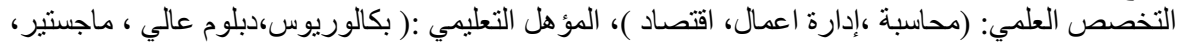

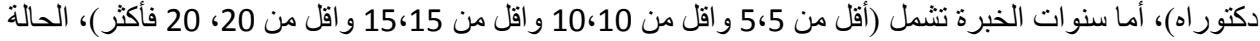

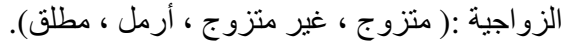

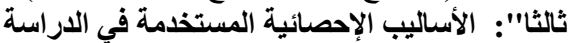

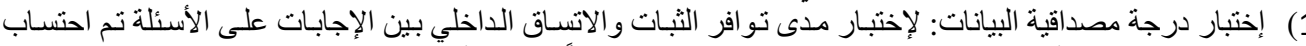

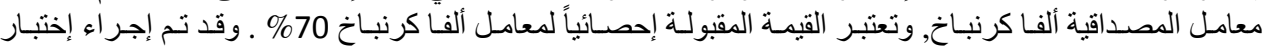

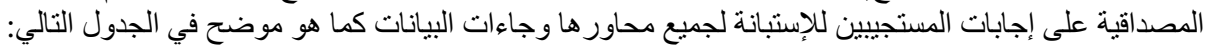


The Effect of strategic management.....

جدول (1). بيانات إختبار كرنباخ ألفا

\begin{tabular}{|c|c|}
\hline ق قيمة كرنباخ & العبار ات \\
\hline 0.83 & عبار ات الفرضية الأولى (توجد أثر ذو دلالة إحصائية عند مستوى (0.05) للهيكل التنظيمى على إتخاذ \\
\hline 0.77 & عبار ات الفرضية الثانية (توجد أثر ذو دلالة إحصائية عند مستوى (0.05) للانظمة و التعليمات على الإداري \\
\hline 0.72 & القرار الإداري) الفرضية الثالثة (توجد أثر ذو دلالة إحصائية عند مستوى (0.05) للتمكين الإداري على إتخاذ \\
\hline 0.81 & عبار ات الفرضية الر ابعة (توجد أثر ذو دلالة إحصائية عند مستوى (0.05) للتفويض الإداري على إتخاذ \\
\hline 0.74 & القرار ات على إتخاذ القرار الإدارية (توجد أثر ذو دلالة إحصائية عند مستوى (0.05) للمشاركة في إتخاذ \\
\hline 0.83 & القبار الإداري) الفرضية السادسة (توجد أثر ذو دلالة إحصائية عند مستوى (0.05) النظم الإدارية على إتخاذ \\
\hline 0.76 & القرار الإداري) الفرضية السابعة (توجد أثر ذو دلالة إحصائية عند مستوى (0.05) القرارات الإدارية على إتخاذ \\
\hline 0.87 & جميع عبار ات الإستبانة \\
\hline
\end{tabular}

(1) أعلاه تو افر درجة عالية جداً من الثبات الداخلي في الإجابات ما يمكننا من الاعتماد على هذه الإجابات في تحقيق أهداف الدر اسة وتحليل بياناتها.

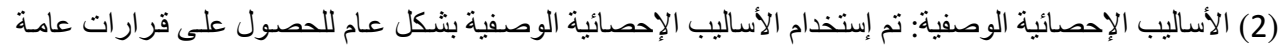

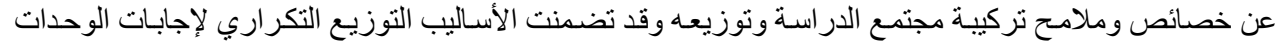
المبحوثنة.

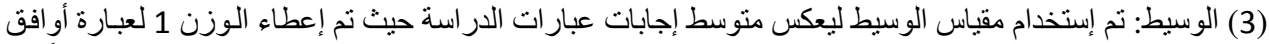

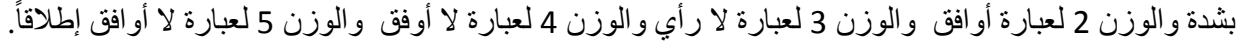

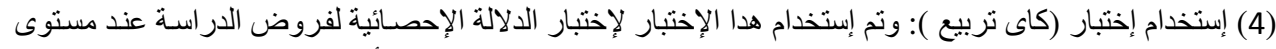

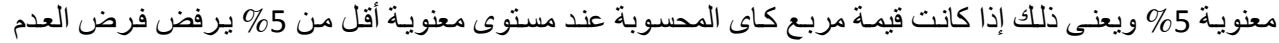

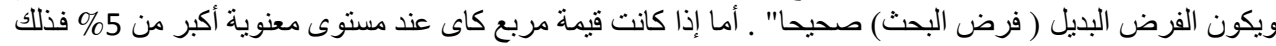

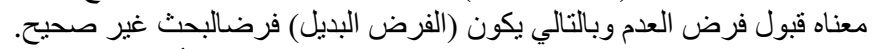

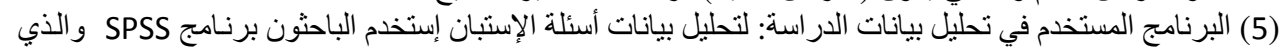

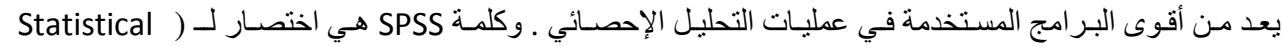
(Package For Social Science

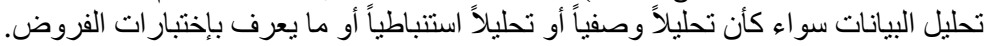

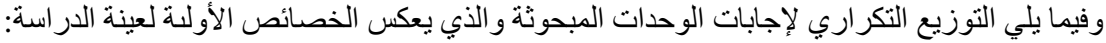

لمعرفة وجهة نظر المبحوثين حول (النوع) وقد منحو ا خيار ات الإجابة التالية (ذكر ، أنثى) وقد جاءت الإجابات من وجهة نظر هم كما يوضحهة نظها الجدول حول التالي:

\begin{tabular}{|c|c|c|}
\hline$\%$ & العدد & النوع \\
\hline 92 & 276 & ذكر \\
\hline 8 & 24 & أنثى \\
\hline 100 & 300 & المجموع \\
\hline
\end{tabular}




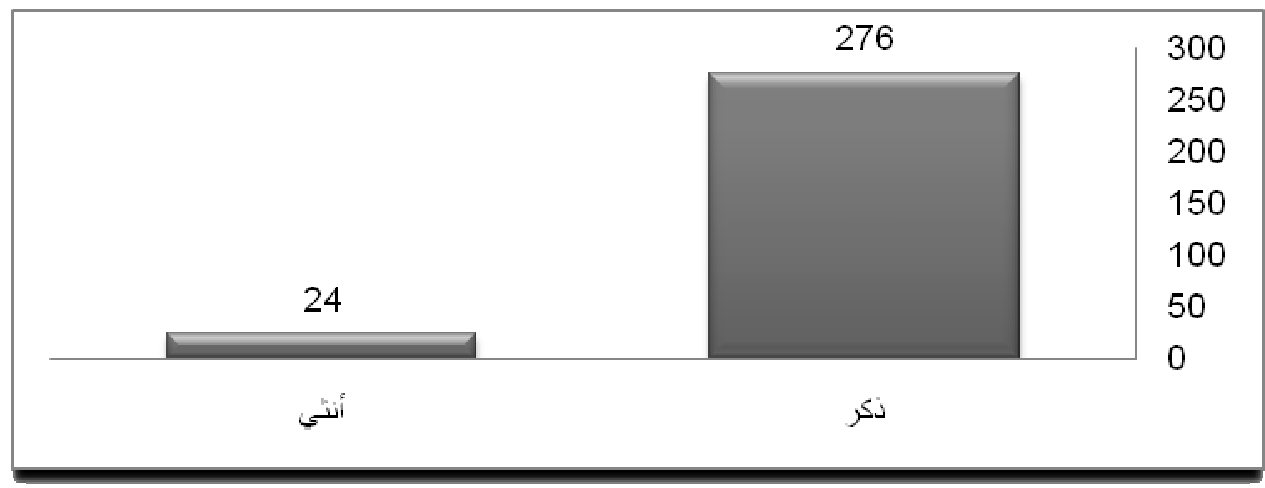

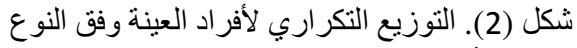

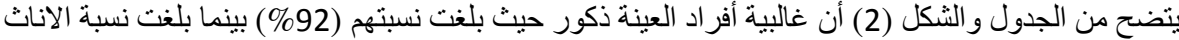

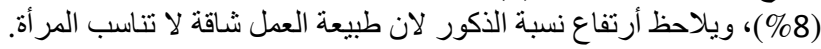

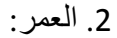

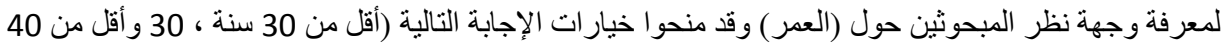

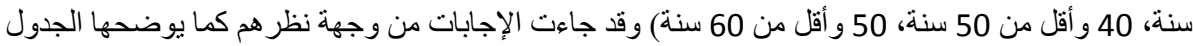

\begin{tabular}{|c|c|c|}
\hline$\%$ & العدد العينة و العد & العمر جدول \\
\hline 19 & 56 & أقل من 30 \\
\hline 30 & 89 & 30 و أقل من 40 \\
\hline 37 & 112 & 40 و أقل من 50 \\
\hline 6 & 18 & 50 و أقَّل من 60 \\
\hline 8 & 25 & أ 60 فأكثر \\
\hline 100 & 300 & المجموع \\
\hline
\end{tabular}

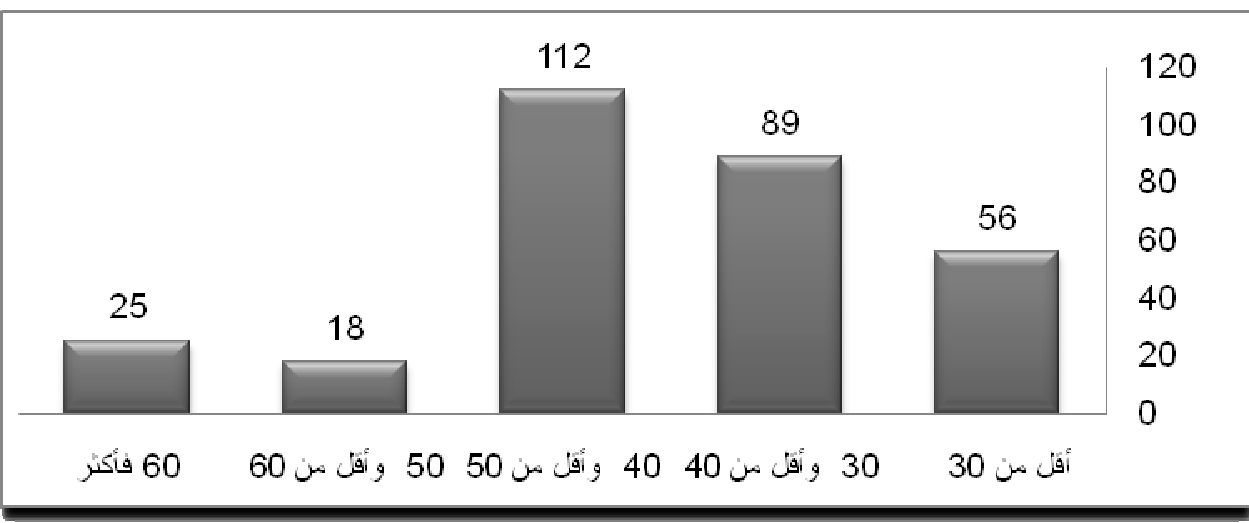

$$
\text { شكل (3). التوزيع التكر اري لأفر اد العينة وفق العمر }
$$

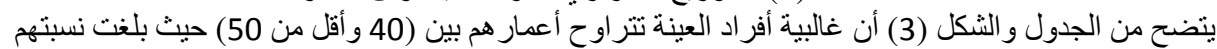

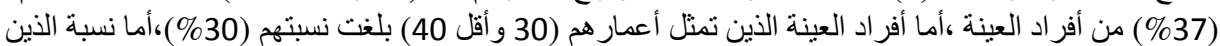
تتمثل أعمار هم ب( أقل من 30) (19\%)،بينما نسبة الذين نتر اوح أعمار هم بين(60 فاكثر) بنسبة (80)، (20)، وكانت 


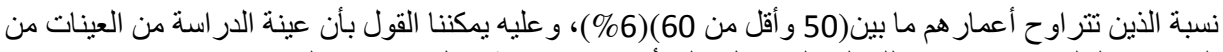

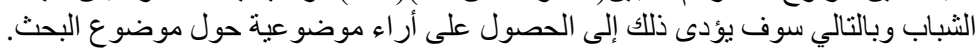

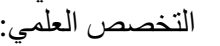
لمعرفة وجهة نظر المبحوثين حول (التخصص العلمي) وقد منحو اليارار ات الإجابة التالية (محاسبة، إدارة اعمال، إقتصاد) وقد جاءت الإجابات من وجهة نظر هم كما يوضحها الجدال الجدول التالي:

جدول (4). التوزيع التكر اري لأفراد العينة التخصص العلمي

\begin{tabular}{|c|c|c|}
\hline$\%$ & العدد & التخصص العلمي \\
\hline 33 & 99 & محاسبة \\
\hline 38 & 115 & إدارة اعمال \\
\hline 29 & 86 & إقتصاد \\
\hline 100 & 300 & المجموع \\
\hline
\end{tabular}

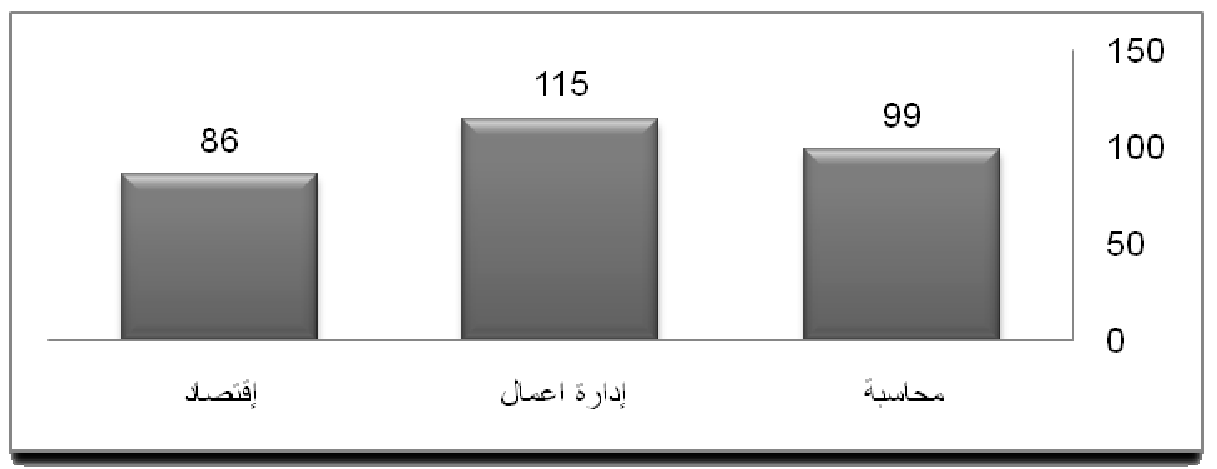

شكل (4). التوزيع التكر اري لأفر اد العينة وفق التخصص العلمي

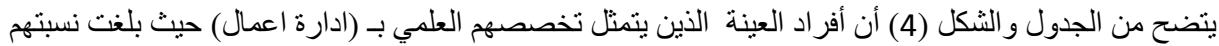

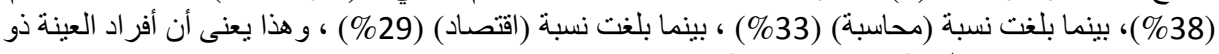
تخصصات ممتازة تفيد الباحثون فى نتائج بحثهم.

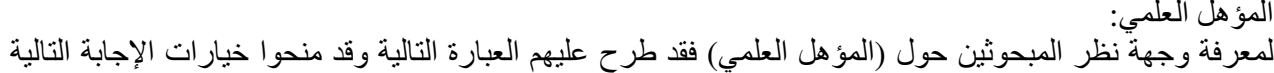

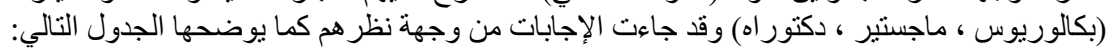

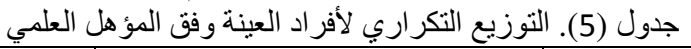

\begin{tabular}{|c|c|c|}
\hline$\%$ & العدد ال العد & المؤهل العلمي \\
\hline 37 & 112 & بكالوريوس \\
\hline 23 & 69 & دبلوم عالي \\
\hline 26 & 78 & ماجستير \\
\hline 14 & 41 & دكتور اه \\
\hline 100 & 300 & المجموع \\
\hline
\end{tabular}


Journal of Social Sciences (COES\&RJ-JSS), 7(4), pp.303-335

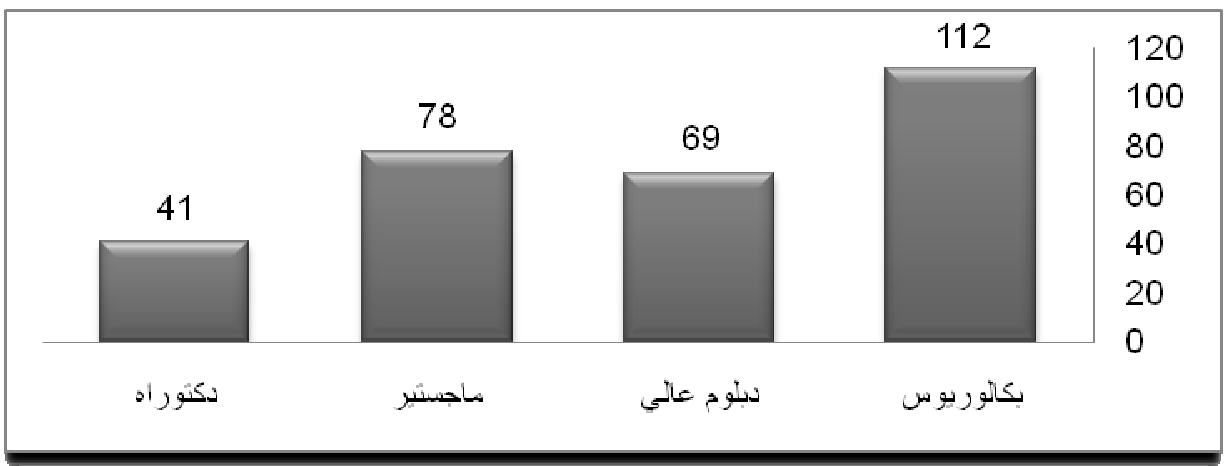

$$
\text { شُكل (5). التوزيع التكر اري لأفراد العينة وفق المؤهل العلمي }
$$

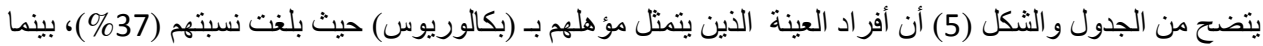

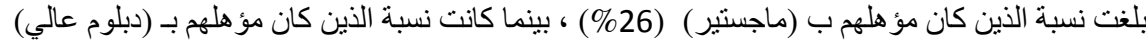
(23\%)،أما نسبة الذين يتمثل مؤهلهم بـ (دكتور اه)(14\%). (14).

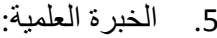

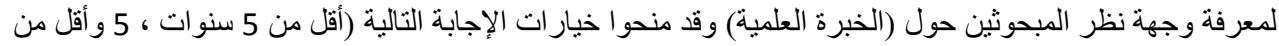

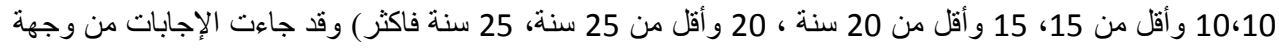
نظر هم كما يوضحها الجدول التالي: الي من

\begin{tabular}{|c|c|c|}
\hline$\%$ & العدد & الخبرة العلمية \\
\hline 8 & 25 & أقلَ من 5 سنوات \\
\hline 12 & 34 & 5 و أقل من 10 \\
\hline 26 & 79 & 10 و أقل من 15 \\
\hline 24 & 71 & 15 و أقل من 20 \\
\hline 30 & 91 & 20 فاكثر \\
\hline 100 & 300 & المجموع \\
\hline
\end{tabular}

\begin{tabular}{|c|c|c|c|c|c|}
\hline 91 & 71 & 79 & & & 100 \\
\hline & & & 34 & 25 & 50 \\
\hline 20 فاكتر & 15 و أقلى من 20 & 10 و أقلى من 15 & 5 و أققل من 10 & أقل من 5 سنوات & \\
\hline
\end{tabular}

شكل (6). التوزيع التكر اري لأفر اد العينة وفق سنو ات الخدمة

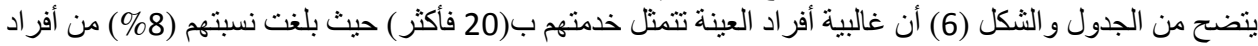

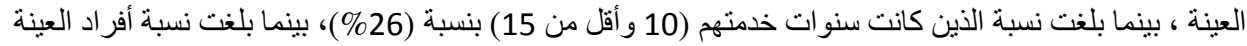

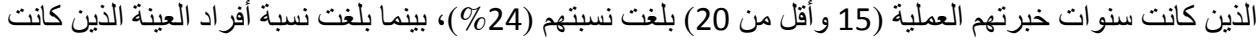

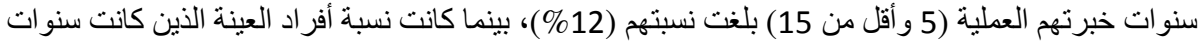


The Effect of strategic management.....

خبرتهم العملية (5 و أقل من 10) (8) و و وعليه يمكننا القول بأن عينة الدر اسة من العينات ذات خبرة علميةعالية

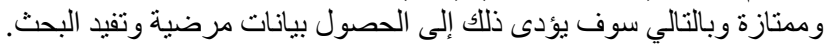
الحالة الزو اجية:

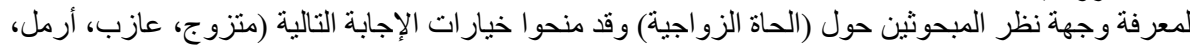

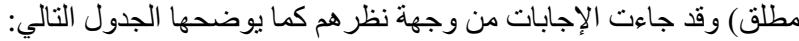

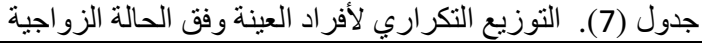

\begin{tabular}{|c|c|c|}
\hline$\%$ & العدد & الحالة الزواجية \\
\hline 52 & 155 & منزوج \\
\hline 23 & 70 & غير منزوج \\
\hline 13 & 40 & أرمل \\
\hline 12 & 35 & مطلق \\
\hline 100 & 300 & المجموع \\
\hline
\end{tabular}

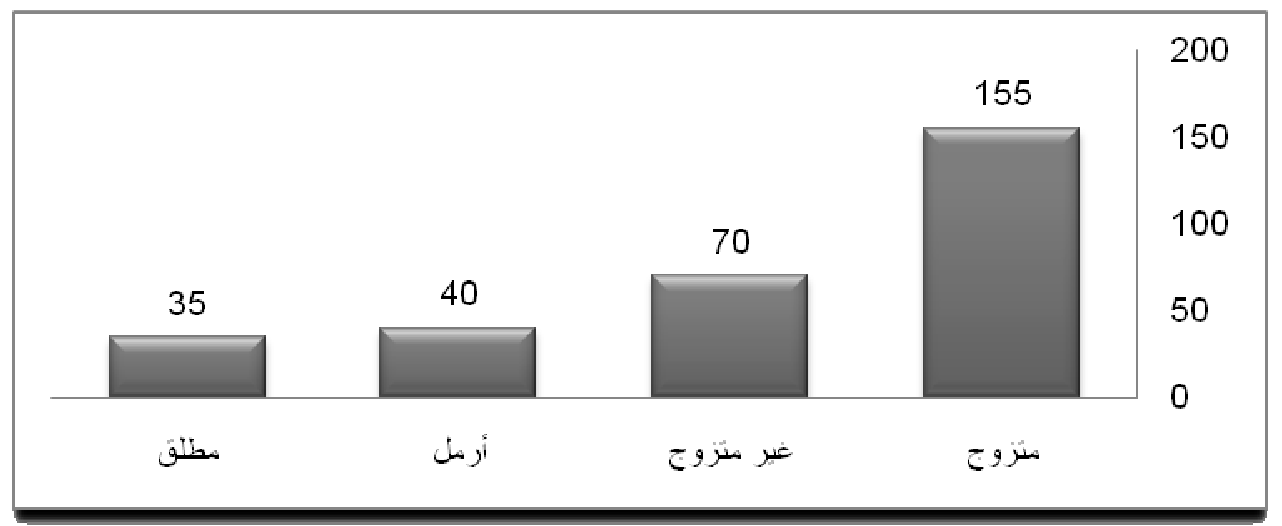

شكل (7). التوزيع التكراري لأفر اد العينة وفق الحالة الزواجية

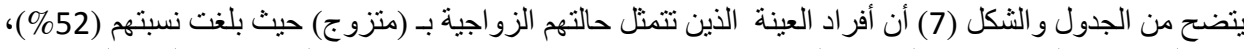

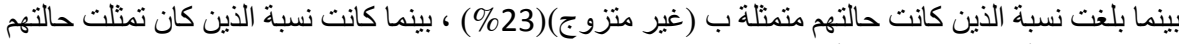

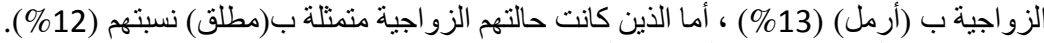

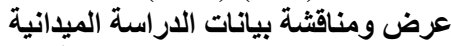

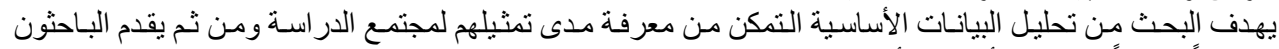

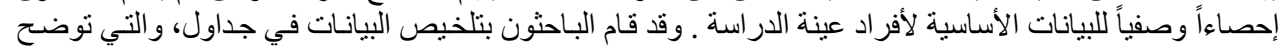

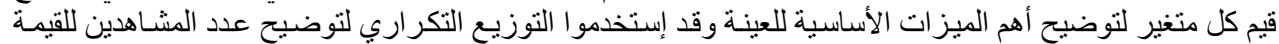

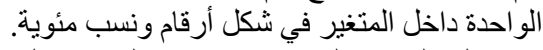

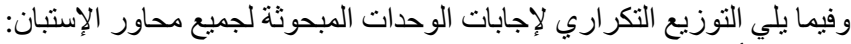

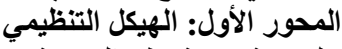

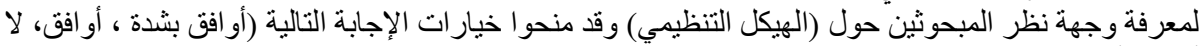

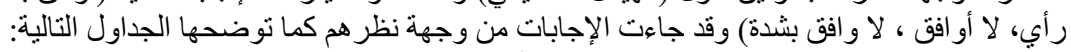

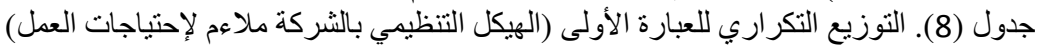

\begin{tabular}{|c|c|c|}
\hline$\%$ & العدد & الإجابة \\
\hline 29.7 & 89 & أوفق بشدة \\
\hline 25 & 75 & أو افق \\
\hline 12 & 36 & لا رأي \\
\hline
\end{tabular}


Journal of Social Sciences (COES\&RJ-JSS), 7(4), pp.303-335

\begin{tabular}{|c|c|c|}
\hline 11 & 33 & لا أوافق \\
\hline 22.3 & 67 & لا أو افق بشدة \\
\hline 100 & 300 & المجموع \\
\hline
\end{tabular}

يتضح من الجدول (8) ارتفاع مجمو عة تكر ار الإجابات في فئة أو افق وأوفق بشدة وهذا يدل على أن معظم مفردات

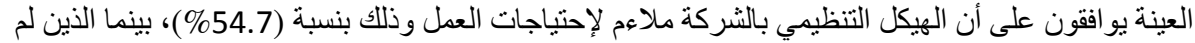

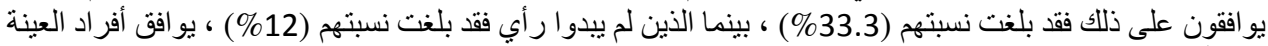

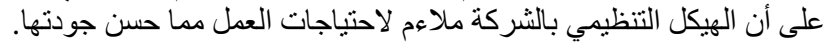

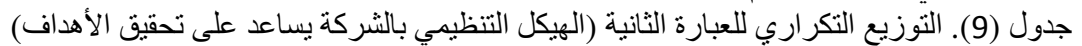

\begin{tabular}{|c|c|c|}
\hline$\%$ & العدد & الإجابة \\
\hline 26.3 & 79 & أوفق بشدة \\
\hline 19 & 57 & أو افق \\
\hline 17.7 & 53 & لا رأي \\
\hline 21.3 & 64 & لا أو افق \\
\hline 15.7 & 47 & لا أو افق بشدة \\
\hline 100 & 300 & المجموع \\
\hline
\end{tabular}

يتضح من الجدول (9) ارتفاع مجموعة تكر ار الإجابات في فئة أو افق و أو افق بشدة وهذا بدل على أن أن معظم مفردات

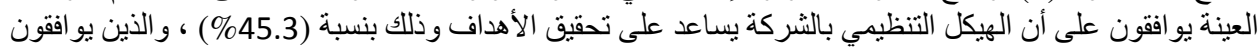

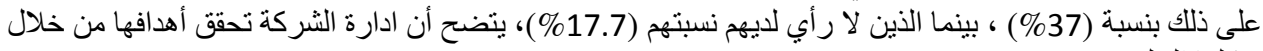
هيكلها السليم.

جدول (10). التوزيع التكراري للعبارة الثالثة (تعمل إدارة الثركة على تطوير الهيكل التنظيمي بصورة مستمرة)

\begin{tabular}{|c|c|c|}
\hline$\%$ & العدد & الإجابة \\
\hline 28.7 & 86 & أوفق بشدة \\
\hline 23 & 69 & أو افق \\
\hline 17.6 & 53 & لا رأي \\
\hline 14.7 & 44 & لا أو افق \\
\hline 16 & 48 & لا أوافق بشدة \\
\hline 100 & 300 & المجموع \\
\hline
\end{tabular}

يتضح من الجدول (10) ارتفاع مجمو عة تكر ار الإجابات في فئة أو افق وأو افق بشدة وهذا يدل على أن معظم مفردات

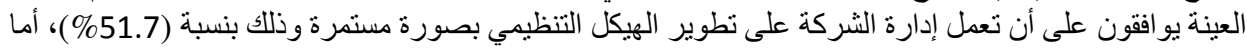

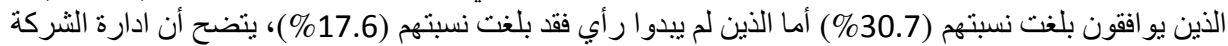

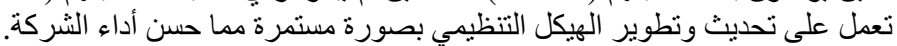
جدول (11). التوزيع التكر اري للعبارة الر ابعة (هناللك مستوى عالى من الاتصـال بين أجز اء الهيكل التهن التظيمي في

\begin{tabular}{|c|c|c|}
\hline \multicolumn{3}{|c|}{ الشركة) } \\
\hline$\%$ & العدد & الإجابة \\
\hline 27.7 & 83 & أوفق بشدة \\
\hline 25.3 & 76 & أو افق \\
\hline 17.4 & 52 & لا رأي \\
\hline 12.3 & 37 & لا أو افق \\
\hline 17.3 & 52 & لا أو افق بشدة \\
\hline 100 & 300 & المجموع \\
\hline
\end{tabular}

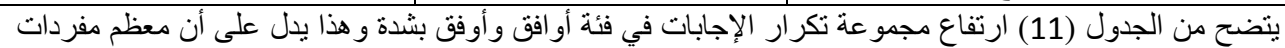

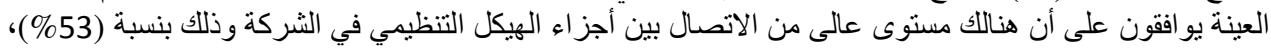


بينما بلغت نسبة غير الموافقون (29.6\%)، أما الذين لم يبدوا رأي فقد بلغت نسبتهم (17.4\%)، نلاحظ أن هنالك

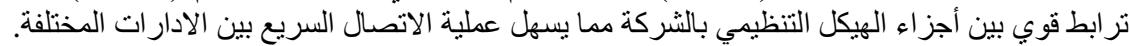

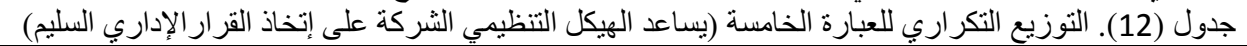

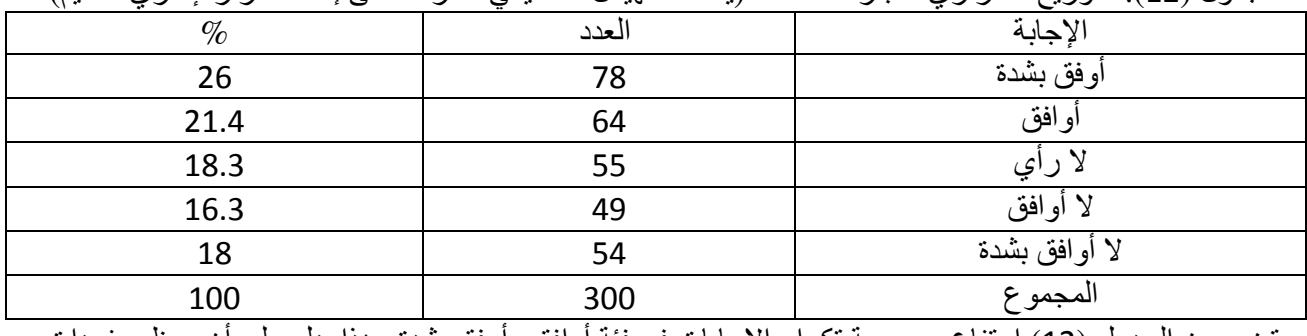

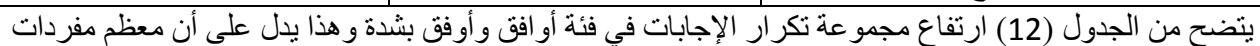

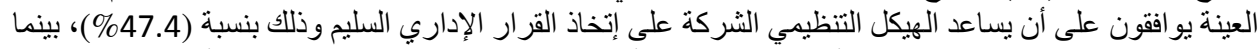

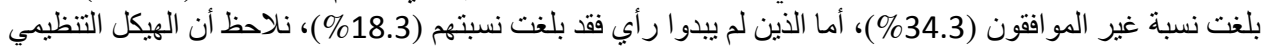

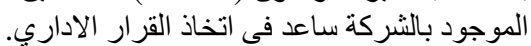

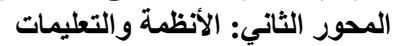

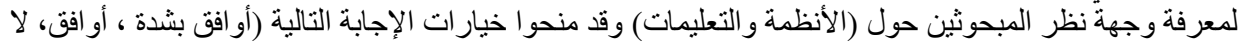

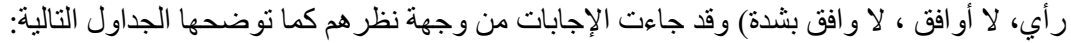

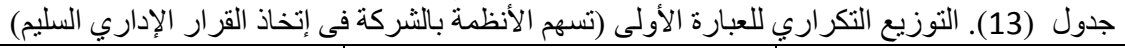

\begin{tabular}{|c|c|c|}
\hline$\%$ & العدد & الإجابة \\
\hline 28.7 & 86 & أوفق بشدة \\
\hline 19 & 57 & أو افق \\
\hline 12.7 & 38 & لا رأي \\
\hline 17.3 & 52 & لا أو افق \\
\hline 22.3 & 67 & لا أو افق بشدة \\
\hline 100 & 300 & المجموع \\
\hline
\end{tabular}

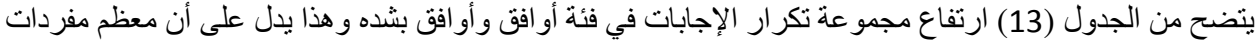

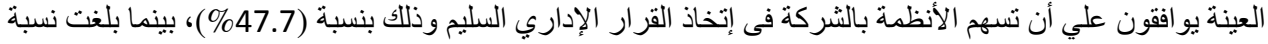

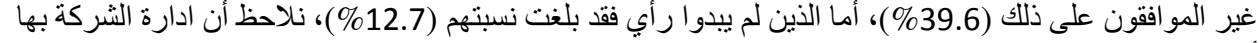
أنظمة سليمة ساعدت في اتخاذ القرار السليم. جدول (14). التوزيع التكر اري للعبارة الثانية (تتوفر لإى الثركة أنظمة ممتازة)

\begin{tabular}{|c|c|c|}
\hline$\%$ & العدد & الإجابة \\
\hline 26.3 & 79 & أوفق بشدة \\
\hline 19.3 & 58 & أو افق \\
\hline 13 & 39 & لا رأي \\
\hline 9 & 27 & لا أو افق \\
\hline 32.3 & 97 & لا أوافق بشدة \\
\hline 100 & 300 & المجموع \\
\hline
\end{tabular}

يتضح من الجدول (14) ارتفاع مجمو عة تكرار الإجابات في فئة أو افق وأوفق بشدة وهذا يدل على أن معظم مفردات

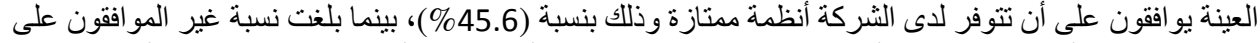

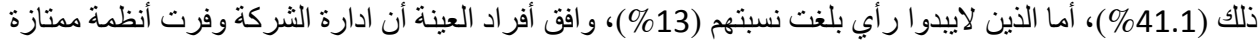


Journal of Social Sciences (COES\&RJ-JSS), 7(4), pp.303-335

جدول (15). التوزيع التكراري للعبارة الثالثة (ساعدت الأنظمة والتعليمات على تطوير القرار الإداري بالثركة)

\begin{tabular}{|c|c|c|}
\hline$\%$ & العدد & الإجابة \\
\hline 29.6 & 89 & أوفق بشدة \\
\hline 17.7 & 53 & أو افق \\
\hline 14 & 42 & لا رأي \\
\hline 13.7 & 41 & لا أو افق \\
\hline 25 & 75 & لا أو افق بشدة \\
\hline 100 & 300 & المجموع \\
\hline
\end{tabular}

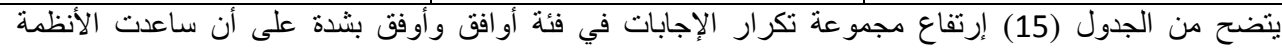

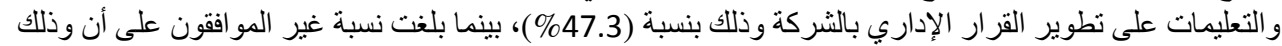
نسبة (38.7\%)، أما نسبة الذين لا رائ لايهم (14\%)، يتضح أن أن ادارة الثركة الانظمة والتعليمات المتوفرة بها

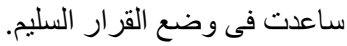
جدول (16). التوزيع التكر اري للعبارة الر ابعة (تهتم الثركة بالتحديث المستمر للأنظمة)

\begin{tabular}{|c|c|c|}
\hline$\%$ & العدد & الإجابة \\
\hline 31 & 93 & أوفق بشدة \\
\hline 17.3 & 52 & أو افق \\
\hline 14.2 & 43 & لا رأي \\
\hline 8.7 & 26 & لا أو افق \\
\hline 28.7 & 86 & لا أو افق بشدة \\
\hline 100 & 300 & المجموع \\
\hline
\end{tabular}

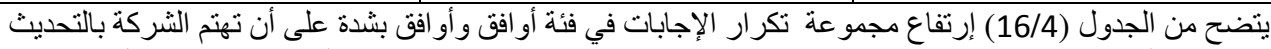

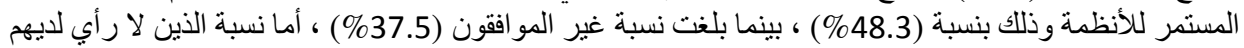
(14.2\%)، يتضح أن إدارة الثركة تهتم بالتحديث المستمر للانظمة لمو اكبة التطور لـات.

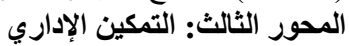
لمعرفة وجهة نظر المبحوثين حول (التمكين الإداري) وقد منحوا خيار الات الإجابة التالية (أو افق بشدة ، أو افق، لا رأي،

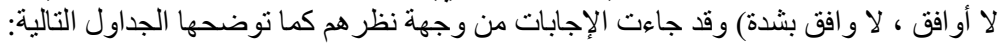

جدول (17). التوزيع التكراري للعبارة الأولى (تعمل الثركة على مشاركة الموظفين في إتخاذ القرار الإداري)

\begin{tabular}{|c|c|c|}
\hline$\%$ & العدد & الإجابة \\
\hline 27.7 & 83 & أوفق بشدة \\
\hline 19.7 & 59 & أو افق \\
\hline 21 & 33 & لارأي \\
\hline 32.7 & 98 & لا أو افق \\
\hline 9 & 27 & لا أو افق بشدة \\
\hline 100 & 300 & المجموع \\
\hline
\end{tabular}

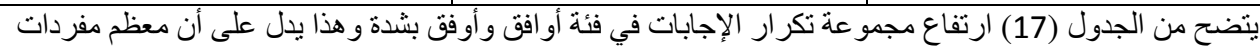

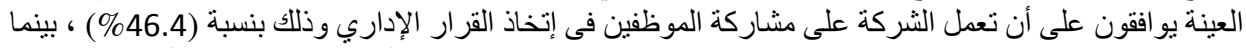

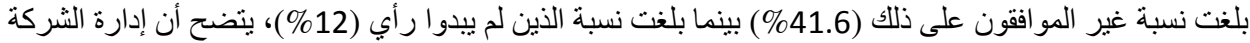

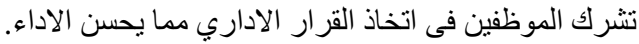
جدول (18). التوزيع التكر اري للعبارة الثنانية (تدعم الثركة الموظفين لزيادة الثقة)

\begin{tabular}{|c|c|c|}
\hline$\%$ & العدد & الإجابة \\
\hline 25.7 & 77 & أوفق بشدة \\
\hline 22.7 & 68 & أو افق \\
\hline 15.3 & 46 & لار رأي \\
\hline
\end{tabular}


The Effect of strategic management.....

\begin{tabular}{|c|c|c|}
\hline 13 & 39 & لا أو افق \\
\hline 23.3 & 70 & لا أو افق بشدة \\
\hline 100 & 300 & المجموع \\
\hline
\end{tabular}

يتضح من الجدول (18) ارتفاع مجمو عة تكر ار الإجابات في فئة أوافق و أوفق بشدة و هذا يدل على أن معظم مفردات

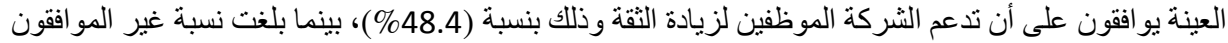

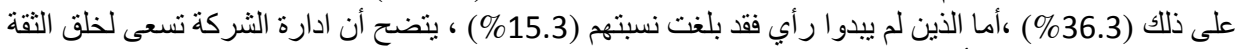
بين الموظفين مما يحسن أدائهم. جدول (19). التوزيع التكراري للعبارة الثالثة (تتبع الثركة نظام الحوافز لتشجيع الموظفين)

\begin{tabular}{|c|c|c|}
\hline$\%$ & العدد & الإجابة \\
\hline 24.3 & 73 & أوفق بشدة \\
\hline 19.7 & 59 & أو افق \\
\hline 18.3 & 55 & لا رأي \\
\hline 14 & 42 & لا أو افق \\
\hline 23.7 & 71 & لا أو افق بشدة \\
\hline 100 & 300 & المجموع \\
\hline
\end{tabular}

يتضح من الجدول (19) ارتفاع مجمو عة تكر ار الإجابات في فئة أو افق وأوفق بشدة وهذا يدل على أن معظم مفردات

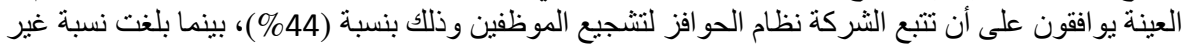

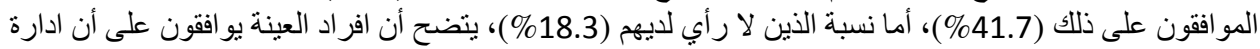

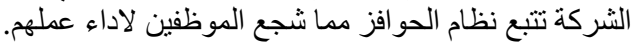

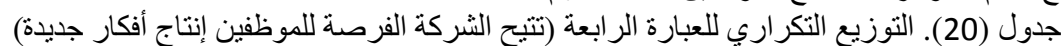

\begin{tabular}{|c|c|c|}
\hline$\%$ & العدد & الإجابة \\
\hline 22 & 66 & أوفق بشدة \\
\hline 26.4 & 79 & أو افق \\
\hline 17 & 51 & لا رأي \\
\hline 12.3 & 37 & لا أو افق \\
\hline 22.3 & 67 & لا أو افق بشدة \\
\hline 100 & 300 & المجموع \\
\hline
\end{tabular}

بتضح من الجدول (20) ارتفاع مجمو عة تكرار الإجابات في فئة أو افق وأوفق بشدة و هذا بدل على أن معظم مفردات

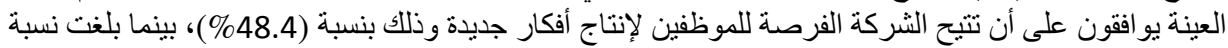

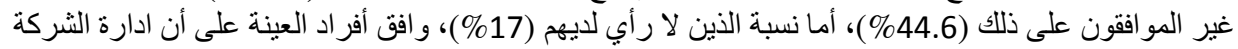

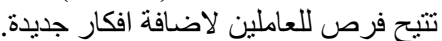

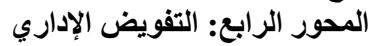

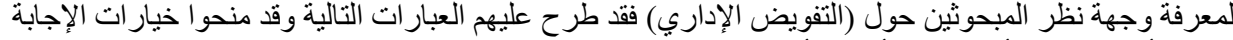
التالية (أو افق بشدة ، أو افق، لا رأي، لا أو افق ، لا و افق بشدة) وقد جاءت الإد الإجابات من وجهة نظر هم كما توضحها الجداول التالية:

جدول (21). التوزيع التكر اري للعبارة الأولى (تعتمد الثركة على تفويض الصلاحيات إلى المستويات الإدارية

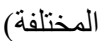

\begin{tabular}{|c|c|c|}
\hline$\%$ & العدد & الإجابة \\
\hline 27.7 & 83 & أوفق بشدة \\
\hline 25.3 & 76 & أو افق \\
\hline 8.3 & 25 & لارأي \\
\hline 21 & 63 & لا أو افق \\
\hline 17.7 & 53 & لا أو افق بشدة \\
\hline 100 & 300 & المجموع \\
\hline
\end{tabular}




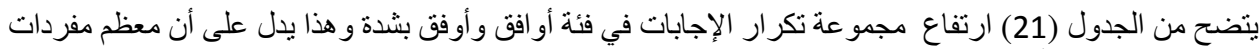

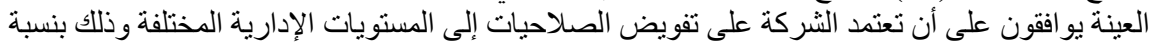

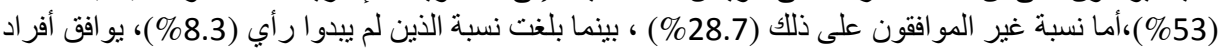

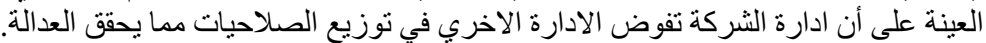

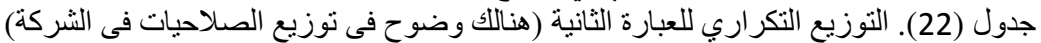

\begin{tabular}{|c|c|c|}
\hline$\%$ & العدد & الإجابة \\
\hline 28 & 84 & أوفق بشدة \\
\hline 21 & 63 & أو افق \\
\hline 13 & 39 & لا رأي \\
\hline 16 & 48 & لا أو افق \\
\hline 22 & 66 & لا أو افق بشدة \\
\hline 100 & 300 & المجموع \\
\hline
\end{tabular}

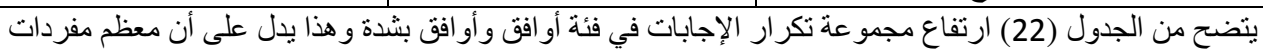

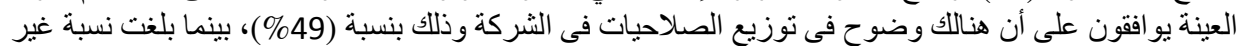

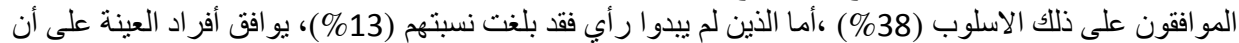

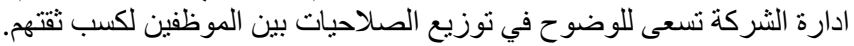

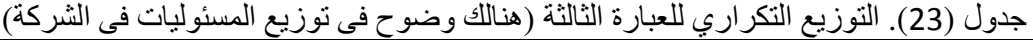

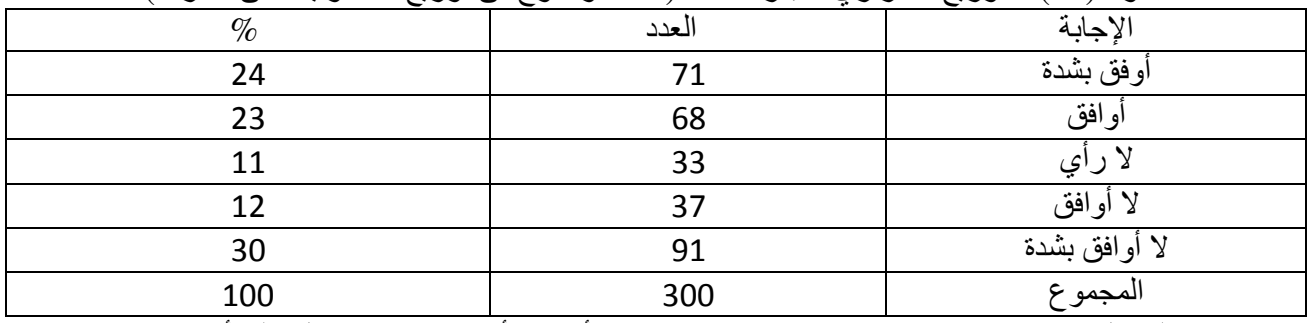

يتضح من الجدول (23) ارتفاع مجمو عة تكرار الإجابات في فئة أوافق و أوفق بشدة و هذا بدل على أن معظم مفردات

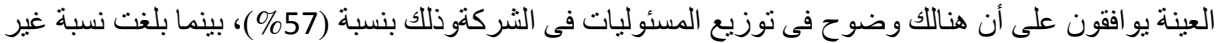

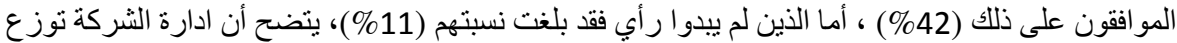

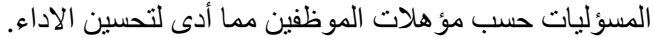
جدول (24). التوزيع التكر اري للعبارة الرابعة (يتميز توزيع الصداحيات بالثفافية)

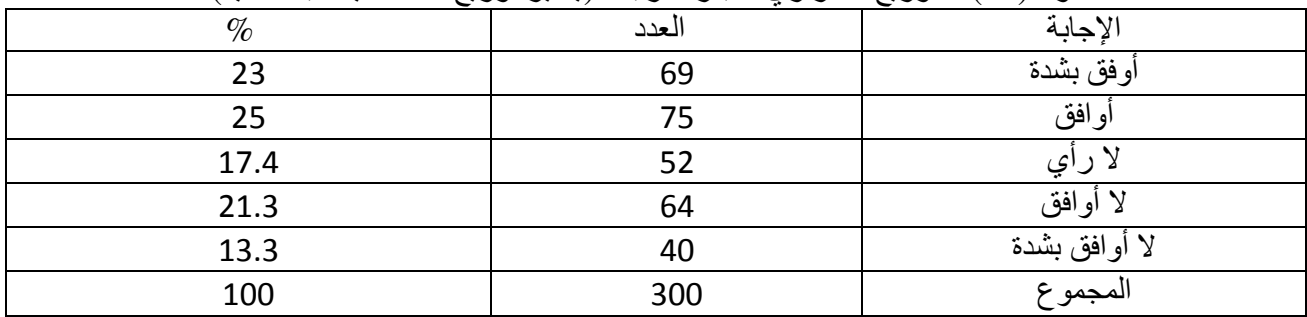

يتضح من الجدول (24) ارتفاع مجمو عة تكر ار الإجابات في فئة أوافق و أوفق بشدة وهذا يدل على أن أن معظم مفردات

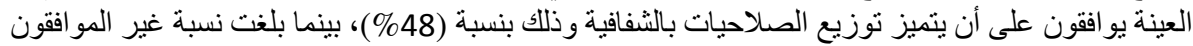

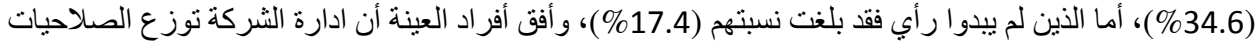
بين الموظفين بصدق و أمانة مما حسن أدائهر.

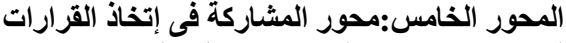

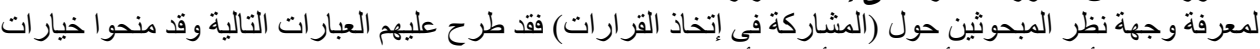

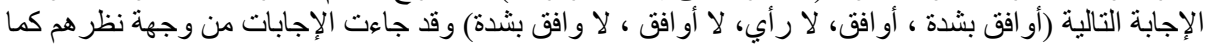
توضحها الجداول التالية: 
The Effect of strategic management.....

جدول (25). التوزيع التكر اري للعبارة الاولى (لا يوجد تدخل للرؤساء فى عمل المرؤسين)

\begin{tabular}{|c|c|c|}
\hline$\%$ & العدد & الإجابة \\
\hline 22 & 66 & أوفق بشدة \\
\hline 27 & 81 & أو افق \\
\hline 15.3 & 46 & لا رأي \\
\hline 17.7 & 53 & لا أو افق \\
\hline 18 & 54 & لا أو افق بشدة \\
\hline 100 & 300 & المجموع \\
\hline
\end{tabular}

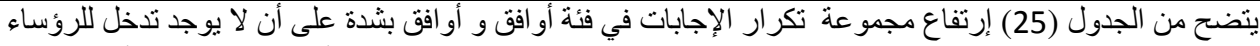

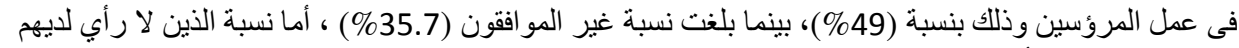

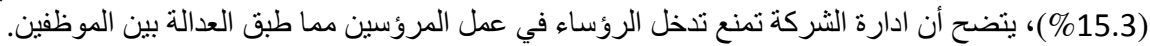

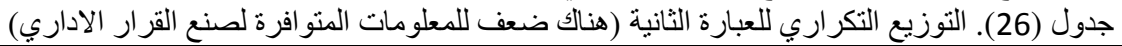

\begin{tabular}{|c|c|c|}
\hline$\%$ & العدد & الإجابة \\
\hline 22.3 & 67 & أوفق بشدة \\
\hline 27.3 & 82 & أو افق \\
\hline 11.4 & 34 & لا رأي \\
\hline 8.7 & 26 & لا أو افق \\
\hline 30.3 & 91 & لا أو افق بشدة \\
\hline 100 & 300 & المجموع \\
\hline
\end{tabular}

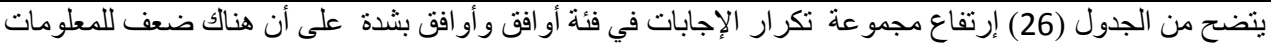

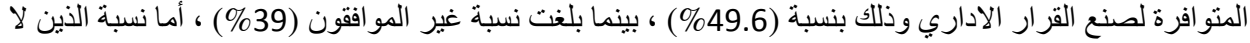

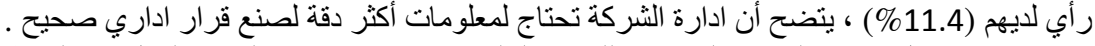

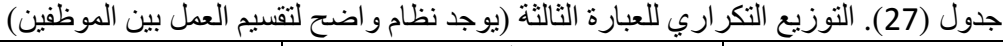

\begin{tabular}{|c|c|c|}
\hline$\%$ & العدد & الإجابة \\
\hline 25 & 75 & أوفق بشدة \\
\hline 23 & 69 & أو افق \\
\hline 18.3 & 55 & لا رأي \\
\hline 12 & 36 & لا أو افق \\
\hline 21.7 & 65 & لا أو افق بشدة \\
\hline 100 & 300 & المجموع \\
\hline
\end{tabular}

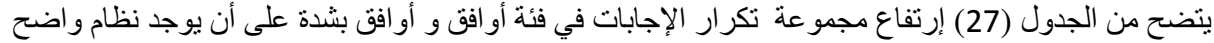

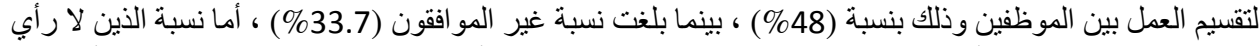

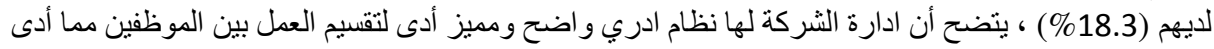

جدول (28). التوزيع التكراري للعبارة الرابعة (لا تدخل العلاقات الثخصية فى صنع القرار الاداري)

\begin{tabular}{|c|c|c|}
\hline$\%$ & العدد & الإجابة \\
\hline 28.4 & 85 & أوفق بشدة \\
\hline 21 & 63 & أو افق \\
\hline 8 & 24 & لا رأي \\
\hline 17.3 & 52 & لا أو افق \\
\hline 25.3 & 76 & لا أو افق بشدة \\
\hline 100 & 300 & المجموع \\
\hline
\end{tabular}


يتضح من الجدول (28) ارتفاع مجمو عة تكرار الإجابات في فئة أو افق و أوفق بثدة و هذا يدل على أن معظم مفردات

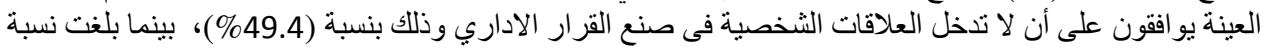

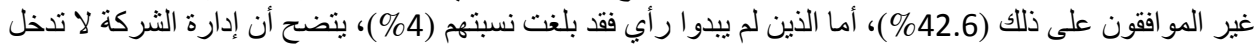

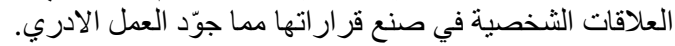

جدول (29). التوزيع التكر اري للعبارة الخامسة (اهتمام الادارة بملاحظات الموظفين أدى لتحسين الاداء)

\begin{tabular}{|c|c|c|}
\hline$\%$ & العدد & الإجابة \\
\hline 26.3 & 79 & أوفق بثدة \\
\hline 27.7 & 83 & أوافق \\
\hline 17.7 & 53 & لا رأي \\
\hline 15.3 & 46 & لا أو افق \\
\hline 13 & 39 & لا أو افق بشدة \\
\hline 100 & 300 & المجموع \\
\hline
\end{tabular}

يتضح من الجدول (29) ارتفاع مجموعة تكرار الإجابات في فئة أو افق و أوفق بشدة و وهذا يدل على أن أن معظم مفردات

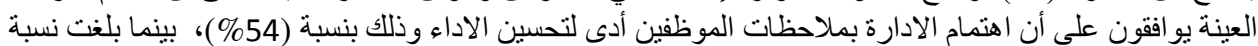

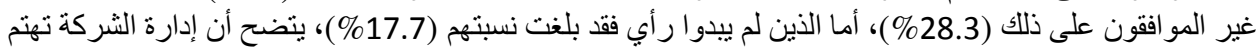
بملاحظات الموظفين مما حسّن الاداء بها.

المحور السادس: النظم الإدارية

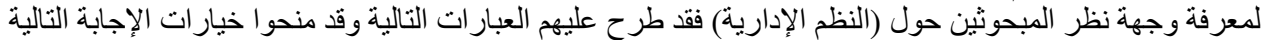

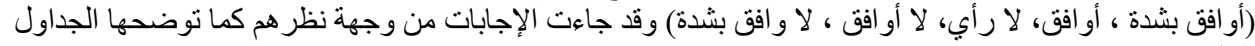

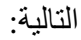

\begin{tabular}{|c|c|c|}
\hline$\%$ & العدد & الإجابة \\
\hline 29.3 & 88 & أوفق بشدة \\
\hline 21.3 & 64 & أو افق \\
\hline 12.4 & 37 & لا رأي \\
\hline 7.3 & 22 & لا أو افق \\
\hline 29.7 & 89 & لا أو افق بشدة \\
\hline 100 & 300 & المجموع \\
\hline
\end{tabular}

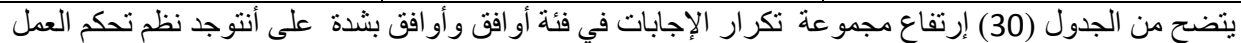

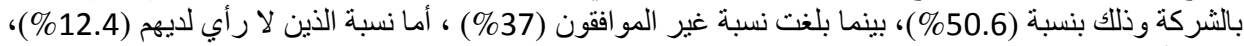

يتضح أن الثركة لها نظم ادارية ممتازة مما ادى للتحكم في العمل بها. جدول (31). التوزيع التكراري للعبارة الثانية (لادى الثركة قو انيين رادعة)

\begin{tabular}{|c|c|c|}
\hline$\%$ & العدد & الإجابة \\
\hline 29 & 87 & أوفق بشدة \\
\hline 21 & 63 & أو افق \\
\hline 18.3 & 55 & لا رأي \\
\hline 12 & 36 & لا أو افق \\
\hline 19.7 & 59 & لا أو افق بشدة \\
\hline 100 & 300 & المجموع \\
\hline
\end{tabular}

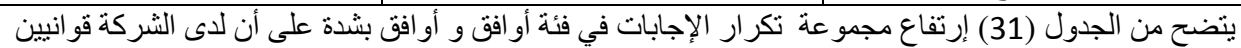

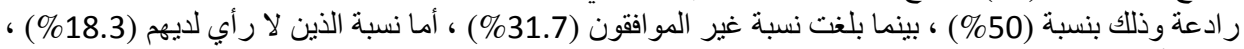
يتضح أن ادارة الثركة وضعت قو انيين رادعة مما ادي التزام الموظفين بعملهم بصورة جيدة. 
The Effect of strategic management.....

جدول (32). التوزيع التكراري للعبارة الثالثة (يلتزم الموظفون بالنظم مما حسن الاداء)

\begin{tabular}{|c|c|c|}
\hline$\%$ & العدد & الإجابة \\
\hline 29.3 & 88 & أوفق بشُدة \\
\hline 21 & 63 & أو افق \\
\hline 17 & 51 & لا رأي \\
\hline 7.7 & 23 & لا أو افق \\
\hline 25 & 75 & لا أو افق بشدة \\
\hline 100 & 300 & المجموع \\
\hline
\end{tabular}

يتضح من الجدول (32) إرتفاع مجموعة تكرار الإجابات في فئة أو افق و أو افق بشدة على أن يلتزم الموظفون بالنظم

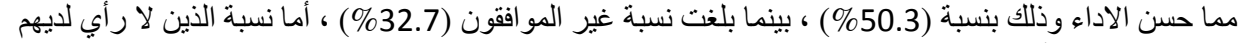

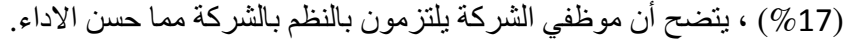

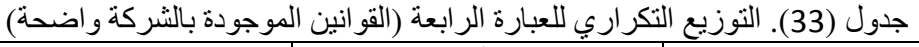

\begin{tabular}{|c|c|c|}
\hline$\%$ & العدد & الإجابة \\
\hline 29.6 & 89 & أوفق بشدة \\
\hline 21 & 63 & أو افق \\
\hline 15.7 & 47 & لا رأي \\
\hline 8.7 & 26 & لا أو افق \\
\hline 25 & 75 & لا أوافق بشدة \\
\hline 100 & 300 & المجموع \\
\hline
\end{tabular}

يتضح من الجدول (33) ارتفاع مجمو عة تكرار الإجابات في فئة أو افق و وأوفق بثدة و هذا يدل على أن أن معظم مفردات

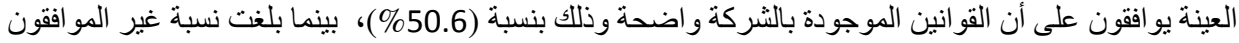

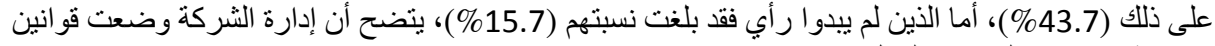

واضحة ساعدت على سير العمل الاداري بها.

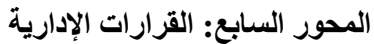

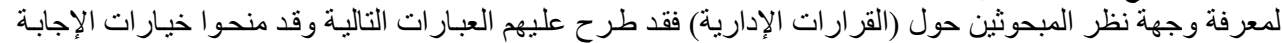

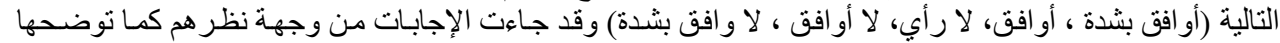

جدول (34). التوزيع التكر اري للعبارة الاولي (القرارات الإدارية تتم عن طريق المشاركة)

\begin{tabular}{|c|c|c|}
\hline$\%$ & العدد & الإجابة \\
\hline 31.6 & 95 & أوفق بشدة \\
\hline 11.7 & 35 & أو افق \\
\hline 15 & 45 & لارأي \\
\hline 25 & 75 & لا أو افق \\
\hline 16.7 & 50 & لا أو افق بشدة \\
\hline 100 & 300 & المجموع \\
\hline
\end{tabular}

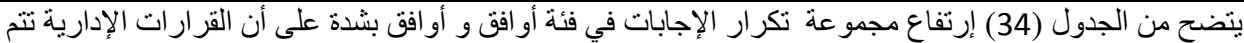

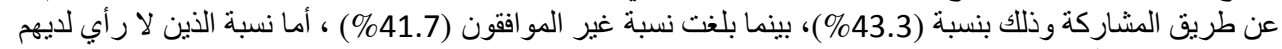

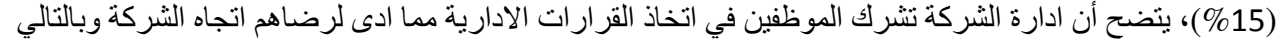

حسن ادائهم. لنفح جدول (35). التوزيع التكراري للعبارة الثانية (القرارات الإدارية تدعم أهداف الثركة)

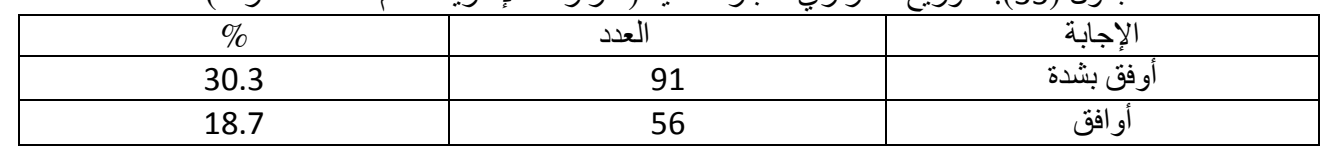


Journal of Social Sciences (COES\&RJ-JSS), 7(4), pp.303-335

\begin{tabular}{|c|c|c|}
\hline 8.7 & 26 & لا رأي \\
\hline 14 & 42 & لا أو افق \\
\hline 28.3 & 85 & لا أو افق بشدة \\
\hline 100 & 300 & المجموع \\
\hline
\end{tabular}

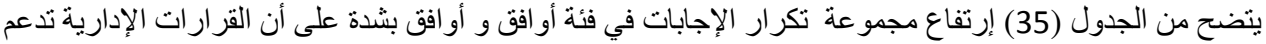

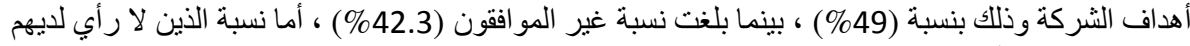

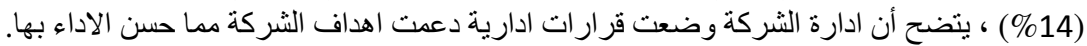

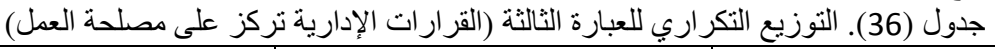

\begin{tabular}{|c|c|c|}
\hline$\%$ & العدد & الإجابة \\
\hline 29 & 87 & أوفق بشدة \\
\hline 18.7 & 56 & أو افق \\
\hline 12 & 36 & لا رأي \\
\hline 14 & 42 & لا أوافق \\
\hline 26.3 & 79 & لا أو افق بشّة \\
\hline 100 & 300 & المجموع \\
\hline
\end{tabular}

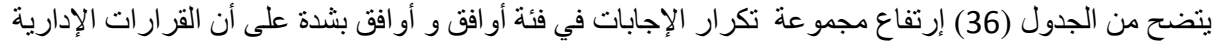

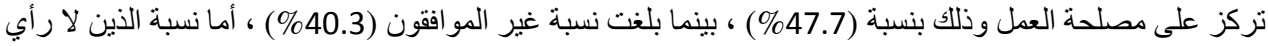

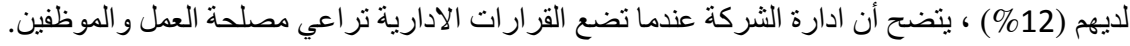
جدول (37). التوزيع التكر اري للعبارة الرابعة (القرارات الإدارية تركز على التئ مصلحة الموظفين)

\begin{tabular}{|c|c|c|}
\hline$\%$ & العدد & الإجابة \\
\hline 32.3 & 97 & أوفق بشدة \\
\hline 10.7 & 32 & أو افق \\
\hline 17.3 & 52 & لا رأي \\
\hline 8.7 & 26 & لا أوافق \\
\hline 31 & 93 & لا أو افق بشدة \\
\hline 100 & 300 & المجموع \\
\hline
\end{tabular}

يتضح من الجدول (37) ارتفاع مجمو عة تكر ار الإجابات في فئة أو افق و وأوفق بشدة و وذا يدل على ألى أن معظم مفردات

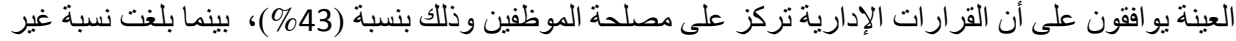

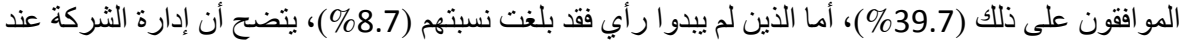

وضعها للقرارات الادارية تر اعي مصلحة الموظفين مدا حسّن الاداداء بها. جدول (38). التوزيع التكر اري للعبارة الخامسة (القرار ات الإدئ الإدارية بالثركة صائبة)

\begin{tabular}{|c|c|c|}
\hline$\%$ & العدد & الإجابة \\
\hline 30.3 & 91 & أوفق بشدة \\
\hline 23 & 69 & أو افق \\
\hline 15 & 45 & لاراي \\
\hline 21 & 63 & لا أو افق \\
\hline 10.7 & 32 & لا أو افق بشدة \\
\hline 100 & 300 & المجموع \\
\hline
\end{tabular}

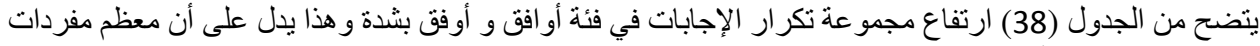

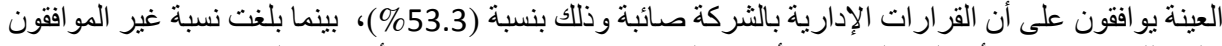

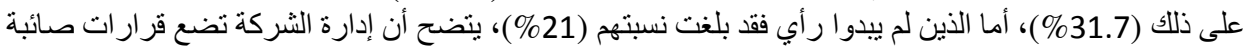
حسب خطتها الاستر اتيجية لسير العمل بها. 
The Effect of strategic management.....

جدول (39). التوزيع التكراري للعبارة السادسة (القرارات الإدارية عادلة)

\begin{tabular}{|c|c|c|}
\hline$\%$ & العدد & الإجابة \\
\hline 28.3 & 85 & أوفق بشدة \\
\hline 21 & 63 & أو افق \\
\hline 11 & 33 & لا رأي \\
\hline 7.7 & 23 & لا أو افق \\
\hline 32 & 96 & لا أو افق بشدة \\
\hline 100 & 300 & المجموع \\
\hline
\end{tabular}

يتضح من الجدول (39) ارتفاع مجمو عة تكرار الإجابات في فئة أوافق و أوفق بشدة وهذا يدل على أن أن معظم مفردات

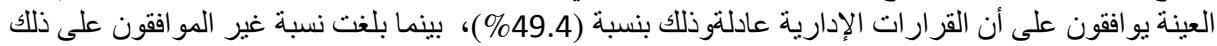

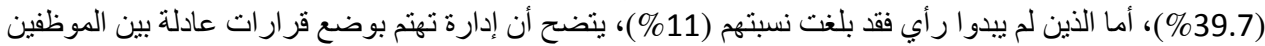

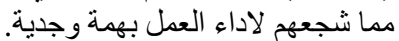
جدول (40). التوزيع التكراري للعبارة السابعة (القرارات الإدارية تتم في اطار النظم المعدول به)

\begin{tabular}{|c|c|c|}
\hline$\%$ & العدد & الإجابة \\
\hline 21.7 & 65 & أوفق بشدة \\
\hline 23.3 & 70 & أو افق \\
\hline 22 & 66 & لا رأي \\
\hline 16.3 & 49 & لا أو افق \\
\hline 16.7 & 50 & لا أو افق بشدة \\
\hline 100 & 300 & المجموع \\
\hline
\end{tabular}

يتضح من الجدول (40) ارتفاع مجمو عة تكرار الإجابات في فئة أوافق و أوفق بشدة و هذا يدل على أن معظم مفردات

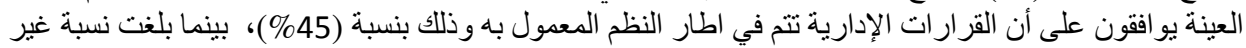

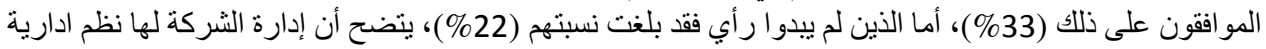

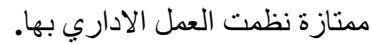
إختبار فرضيات الار نظة اسنة المبيانية

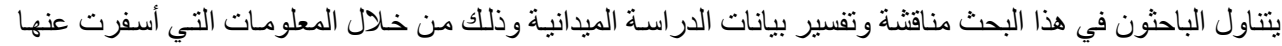

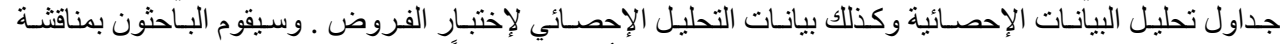

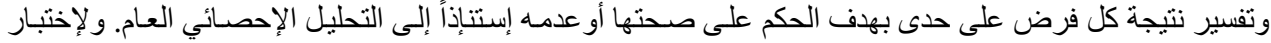

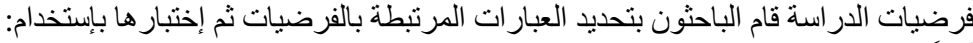

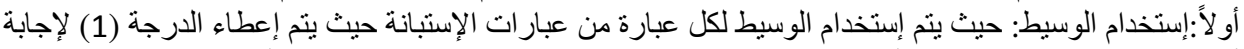

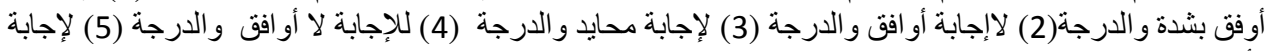
لأو افق بشدة.

ثانياً: إستخدام كآي تربيع :لمعرفة دلالة الفروق في إجابات أفر اد عينة الدر اسة على عبار ات كل فرضية.

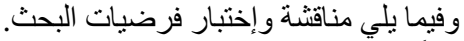

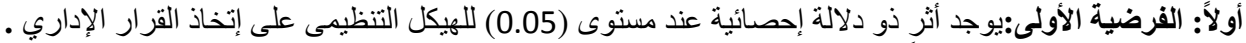

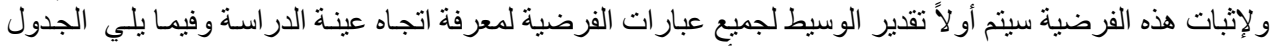

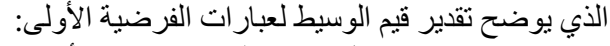
جدول (41). الوسيط لإجابات أفر اد عينة الار استة على عبار ات الفرضية الأولى

\begin{tabular}{|c|c|c|}
\hline التفسير & الوسيط الوسي & 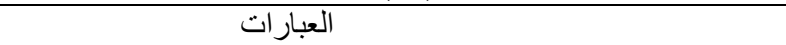 \\
\hline 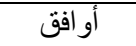 & 2 & الهيكل التنظيمي بالثركة ملاءم لإحتياجات العمل \\
\hline 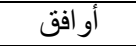 & 2 & الهيكل التنظيمي بالشركة يساعد على تحقيق الأهداف \\
\hline 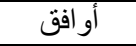 & 2 & تعمل إدارة الثركة على تطوير الهيكل التنظيمي بصورة مستمرة \\
\hline 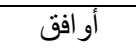 & 2 & هناللك مستوى عالى من الاتصـال بين أجز اء الهيكل التنظيمي في الثركة \\
\hline أو افق بشدة & 1 & يساعد الهيكل التنظيمي الثركة على إتخاذ القرار الإداري السليم \\
\hline
\end{tabular}


يتبين من الجدول (41) مايلي:

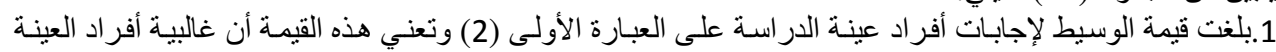

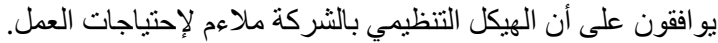

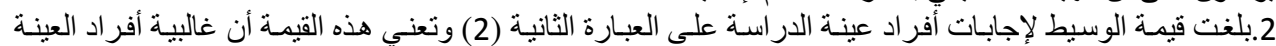

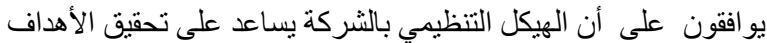

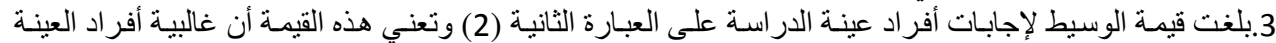

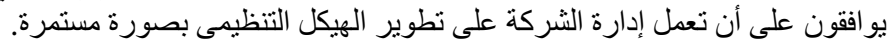

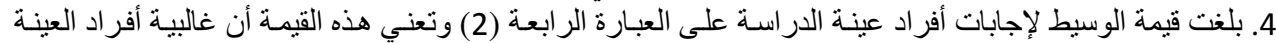

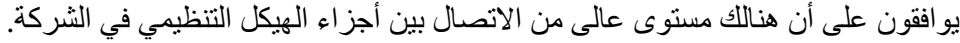

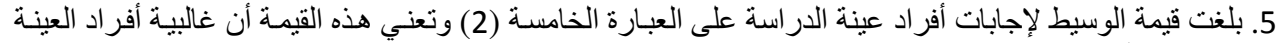

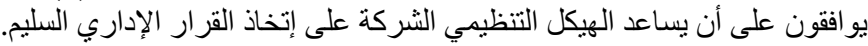

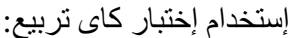
و لإختبار وجود فروق لإئ ذات دلالة إحصائية بين أعداد المو افقون و غير الموافقون للبيانات أعلاه تم إستخدامإختبار مربع

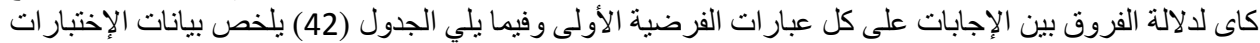
جدول (42). بيانات إختبار مربع كاى لالالة الفروق لإجابات الفرضية الأولى العي

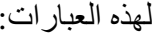

\begin{tabular}{|c|c|c|}
\hline قيمة مربع كاى & 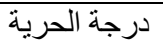 & 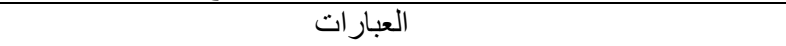 \\
\hline 70.25 & 4 & الهيكل التظظيمي بالثركة ملاءم لإحتياجات العمل \\
\hline 59.93 & 2 & الهيكل التتظيمي بالشركة يساعد على تحقيق الأهداف \\
\hline 80.83 & 2 & تعمل إدارة الثركة على تطوير الهيكل التنظيمي بصورة مستمرة \\
\hline 57.40 & 3 & هنالك مستوى عالى من الاتصال بين أجزاء الهيكل التنظيمي في الشركة \\
\hline 49.33 & 2 & يساعد الهيكل التنظيمي الثركة على إتخاذ القرار الإداري السليم \\
\hline
\end{tabular}

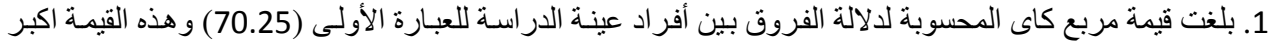

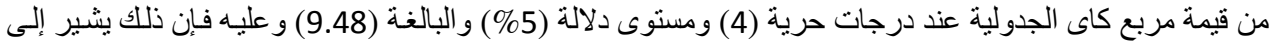

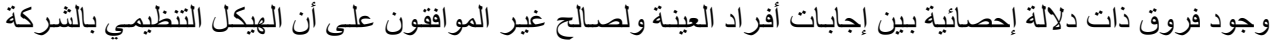

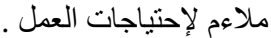

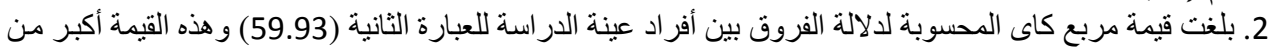

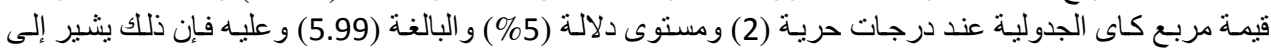

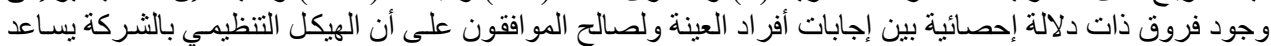
على تحقيق الأهداف . 3. بلغت قيمة مربع كاى المحسوبة لالالة الفروق بين أفر اد عينة الدر اسة للعبارة الثالثة (80.83) وهذه القيمة أكبر من

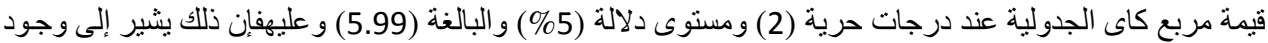

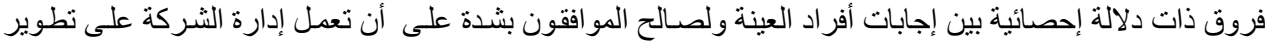

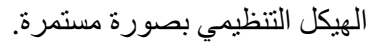

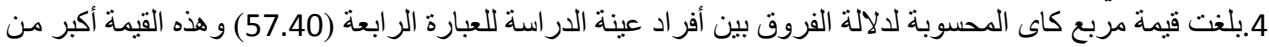

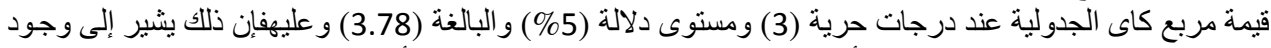

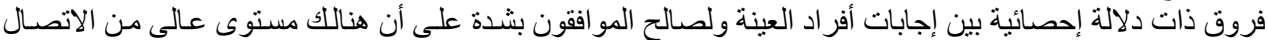

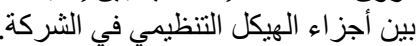

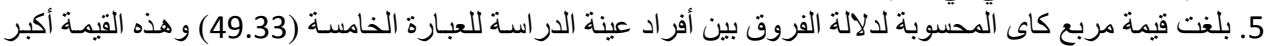

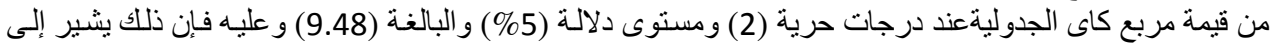

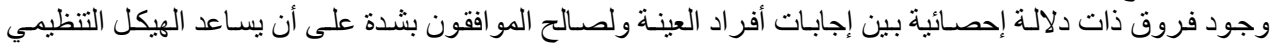
الشركة على إنخاذ القرار الإداري السليه. 
The Effect of strategic management.....

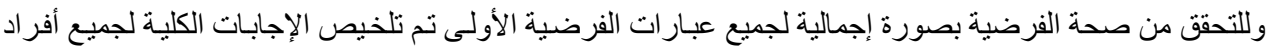

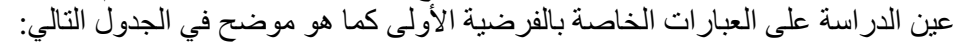

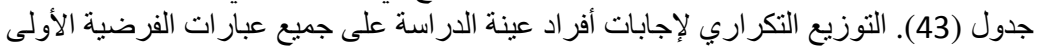

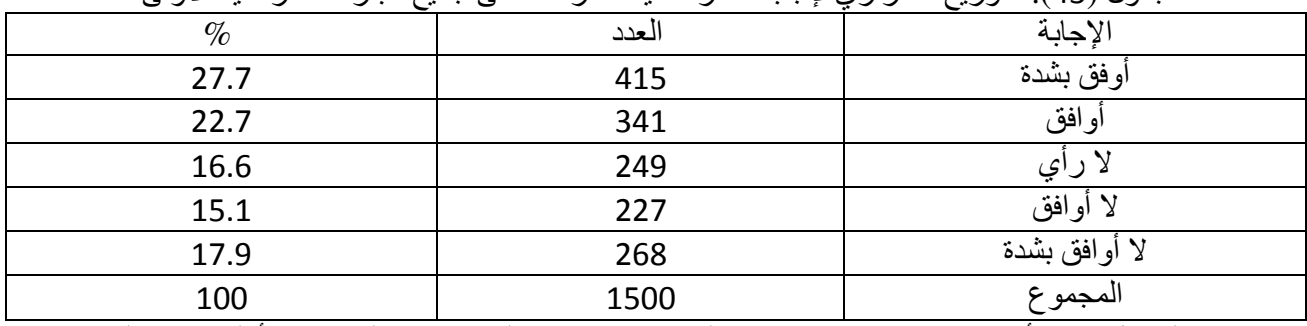

يتبين من الجدول (43) أن نسبة (50.4\%) من عينة الدر اسة يو افقون على عبار ات الفرضية الأولى، بينما بلغت نسبة

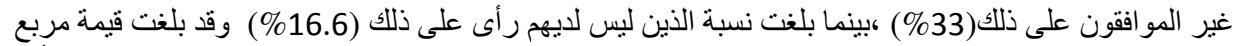

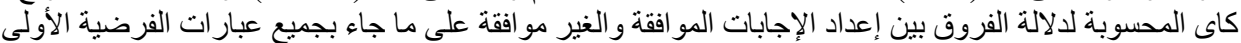

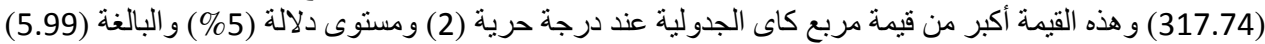

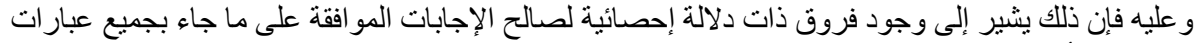
الفرضية الأولى.

وما تقدم يتضح أن فرضية الدر اسة الأولى والتي نصت على أن يوجد أثر ذو دلالة إحصائية عند مستوى(0.05)

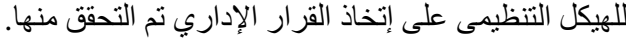
ثانياً: الفرضية الثانية: يوجد أثر ذو دلإلة الإداري إحصائية عند مستوى(0.05) للانظمة و التعليمات على إتخاذ القرار الإداري. و لإثبات هذه الفرضية سيتم أو لاً تقدير الوسيط لجميع عبار ات الفرضية لمعرفة اتجاه عينة الدر اسة وفيما يلي الجدول الذي يوضح تقدير قيم الوسيط لعبار ات الفرضية الفرضية الثانية: جدول (44). الوسيط لإجابات أفراد عينة الدراسة استة على عبار ات الفرضية الثانية

\begin{tabular}{|c|c|c|}
\hline التفسير & 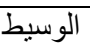 & 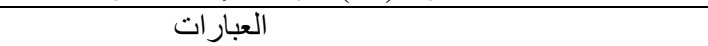 \\
\hline 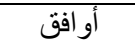 & 2 & تسهم الأنظمة بالثركة فى إتخاذ القرار الإداري السليم \\
\hline 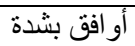 & 1 & تتوفر لاى الثركة أنظمة ممتازة \\
\hline 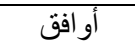 & 2 & ساعدت الأنظمة و التعليمات على تطوير القرار الإداري بالثركة \\
\hline 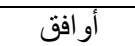 & 2 & تهتم الثركة بالتحديث المستمر للانظمة \\
\hline
\end{tabular}
يتبين من الجدول(44) ما يلي:

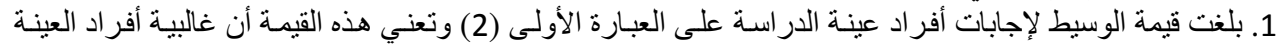

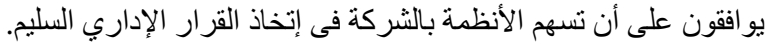

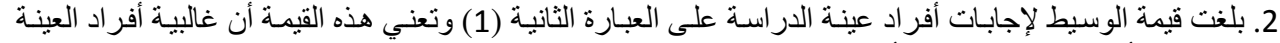

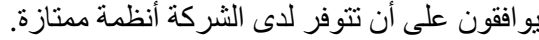

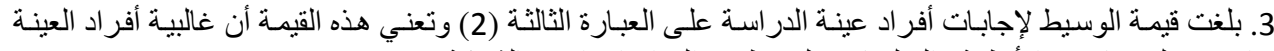
يو افقون على ساعدت الأنظمة والتعليمات على تطوير القرار الإداري الإدي بالثركة.

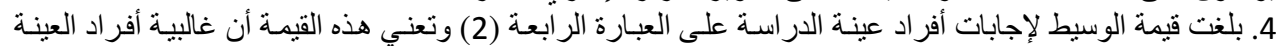
يو افقون على أن هتهتم الثركة بالتحديث النقابث المستمر للأنظمة.

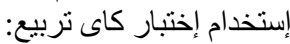

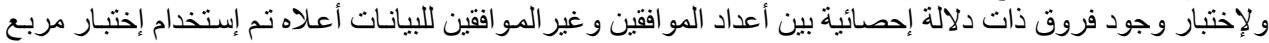

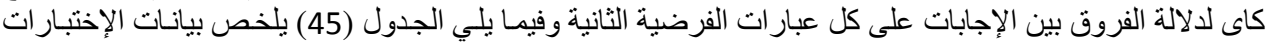
لهذه العبار ات: الاته: 
Journal of Social Sciences (COES\&RJ-JSS), 7(4), pp.303-335

\begin{tabular}{|c|c|c|}
\hline قيمة مربع كاى & الحرية & 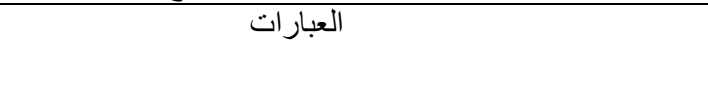 \\
\hline 85.58 & 4 & تسهم الأنظمة بالثركة فى إتخاذ القرار الإداري السليم \\
\hline 70.66 & 4 & تتوفر لاى الشركة أنظمة ممتازة \\
\hline 79.83 & 2 & ساعدت الأنظمة والتعليمات على تطوير القرار الإداري بالثركة \\
\hline 43.66 & 3 & تهتم الثركة بالتحديث المستمر للأنظمة \\
\hline
\end{tabular}

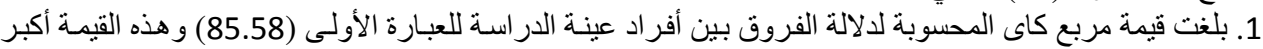

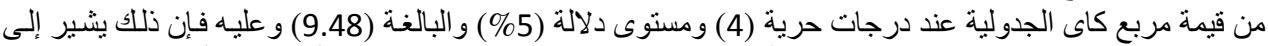

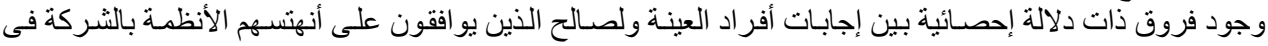
إتخاذ القرار الإداري السليه.

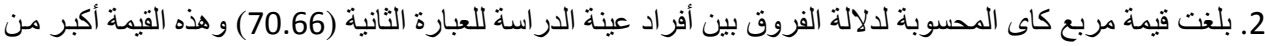

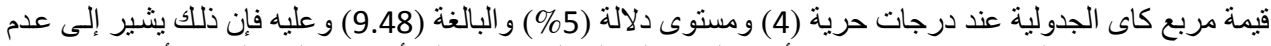

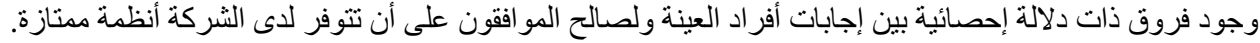

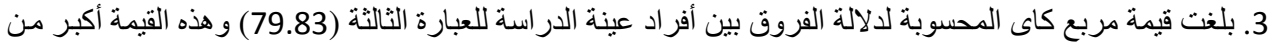

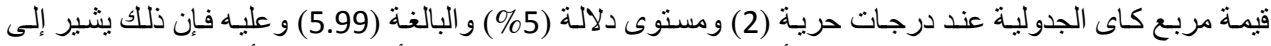

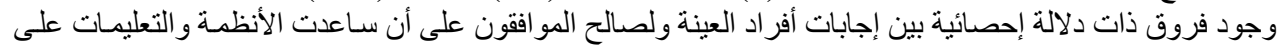

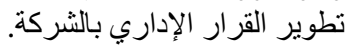

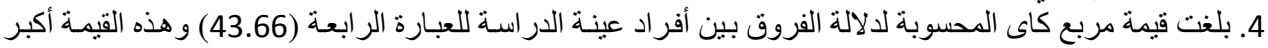

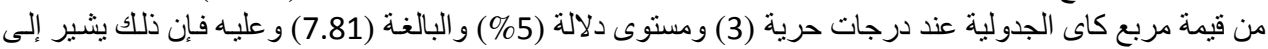

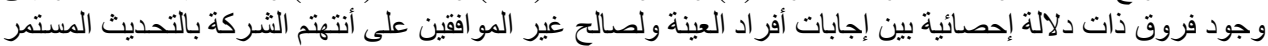

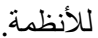

وللتحقق من صحة الفرضية بصورة إجمالية لجميع عبار ات الفرضية الثانية تم تلخيص الإجابات الكلية لجميع أفراد ادلئ

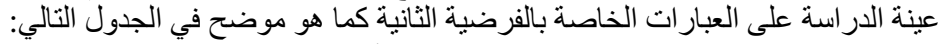

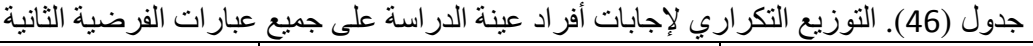

\begin{tabular}{|c|c|c|}
\hline$\%$ & العدد & الإجابة \\
\hline 28.9 & 347 & أوفق بشدة \\
\hline 18.3 & 220 & أو افق \\
\hline 13.5 & 162 & لا رأي \\
\hline 12.2 & 146 & لا أوافق \\
\hline 27.1 & 325 & لا أوافق بشدة \\
\hline 100 & 1200 & المجموع \\
\hline
\end{tabular}

يتبين من الجدول (46) أن نسبة (47.2\%) من عينة الدر اسة يو افقون على عبار ات الفرضية الثانية بينما بلغت نسبة

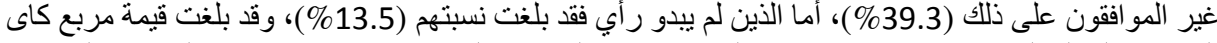

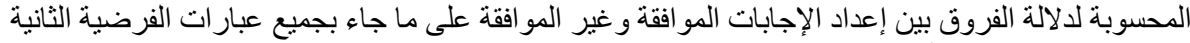

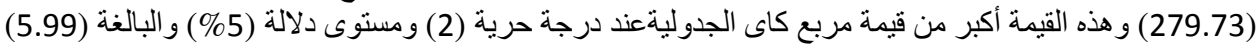

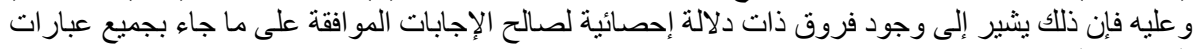
الفرضية الثانية.

وما تقام يتضح أن فرضية الدر اسة الثانية والتي نصت على أن يوجد أنثر ذو دلالة إحصائية عند مستوى(0.05)

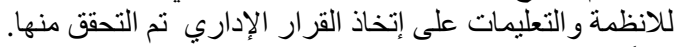

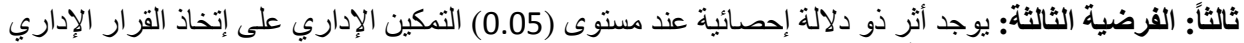

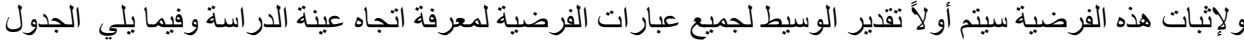

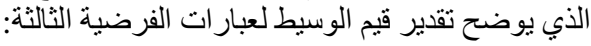


The Effect of strategic management.....

جدول (47). الوسيط لإجابات أفراد عينة الدر اسة على عبار ات الفرضية الثالثة

\begin{tabular}{|c|c|c|}
\hline التفسير & الوسيط & 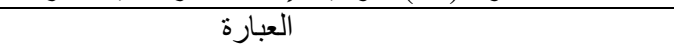 \\
\hline أو افق & 2 & تعمل الشركة على مشاركة الموظفين فى إتخاذ القر ار الإداري \\
\hline أو افق & 2 & تدعم الثركة الموظفين لزيادة التقة \\
\hline لا رأي & 3 & تتبع الشركة نظام الحوافز لتشجيع الموظفين \\
\hline أو افق & 2 & تتيح الشركة الفرصة للعاملين إنتاج أفكار جديدة \\
\hline
\end{tabular}

يتبين من الجدول (47) ما يلي:

1. بلغت قيمة الوسيط لإجابات أفر اد عينة الدر اسة على العى العبارة الأولى (2) وتعني هذه القيمة أن غالبية أفر اد العينة

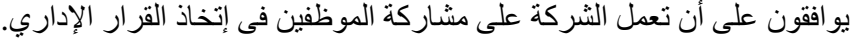

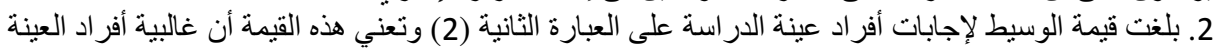

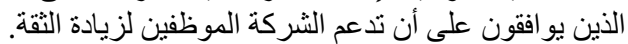

3. بلغت قيمة الوسيط لإجابات أفر اد عينة الدر اسة على الثى العبارة الثالثة (2) وتعني هذه القيمة أن غالبية أفراد العينة

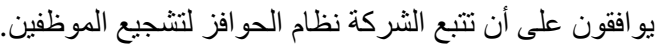
4. بلغت قيمة الوسيط لإجابات أفر اد عينة الدر اسة على العبارة الفئ الر ابعة (2) وتعني هذه القيمة أن غالبية أفر اد العينة

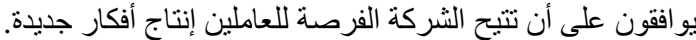

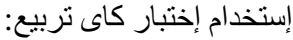

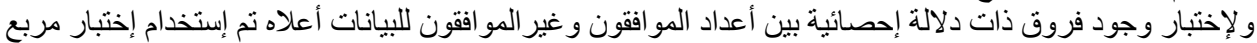

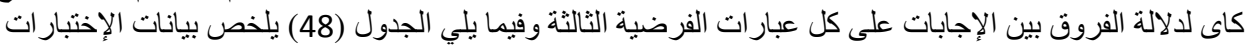

جدول (48). بيانات إختبار مربع كاى لالالة الفروق لإجابات الفرضية الثالثة

\begin{tabular}{|c|c|c|}
\hline قيمة مربع & الحرجية & 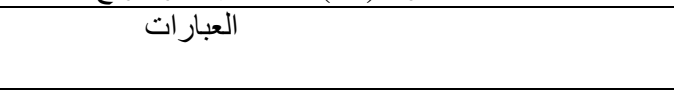 \\
\hline 93.41 & 2 & تعمل الثركة على مشاركة الموظفين فى إتخاذ القرار الإداري \\
\hline 76.33 & 3 & تدعم الثركة الموظفين لزيادة الثقة \\
\hline 98.41 & 2 & تتبع الشركة نظام الحو افز لتشجيع الموظفين \\
\hline 89.16 & 2 & تتيح الثركة الفرصة للعاملين إنتاج أفكار جديدة \\
\hline
\end{tabular}

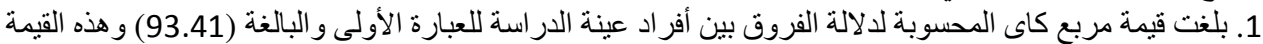

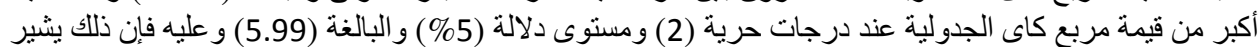

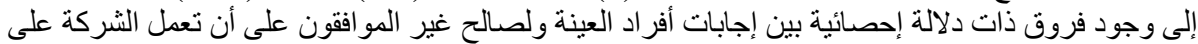

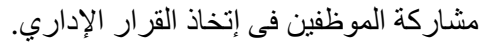

2. بلغت قيمة مربع كاى المحسوبة لدالالة الفروق بين أفر اد عينة الدر اسة للعبارة الثانية (76.33) و هذه القيمة الكبر الكبر من

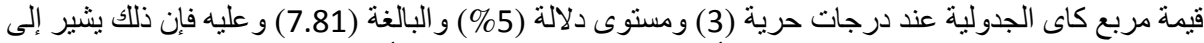

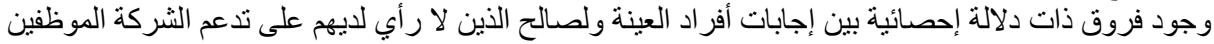
لز بلزادة الثقة.

3. بلغت قيمة مربع كاى المحسوبة لالالة الفروق بين أفر اد عينة الدر اسة للعبارة الثالثة (98.41) و هذه القيمة أكبر من

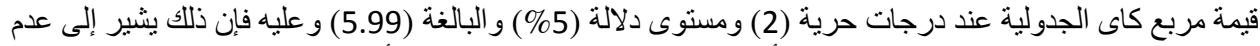
وجود فروق ذات دلالة إحصائية بين إجابات أفر اد العينة ولصالح الموات افقون على أن تتبع الثركة نظام الحوافز الفز لتشجيع الموظفين.

4. بلغت قيمة مربع كاى المحسوبة لدلالة الفروق بين أفر اد عينة الدر اسة للعبارة الر ابعة (89.16) و هذه القيمة أكبر

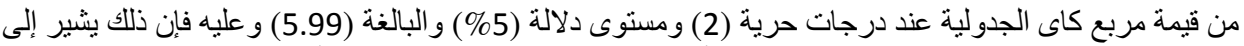
عدم وجود فروق ذات دلالة إحصائية بين إجابات أفر اد العينة ولصالح المو افقون على أن تتيح الثركة الفرصة للعاملين إنتاج أفكار جديدة. 
Journal of Social Sciences (COES\&RJ-JSS), 7(4), pp.303-335

للتحقق من صحة الفرضية بصورة إجمالية لجميع عبار ات الفرضية الثالثة تم تلخيص الإجابات الكلية لجميع أفراد عينة

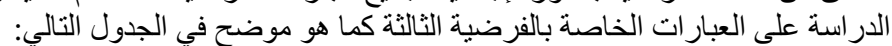

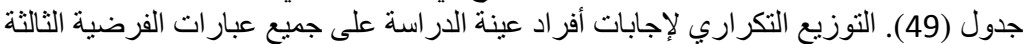

\begin{tabular}{|c|c|c|}
\hline$\%$ & العدد & الإجابة \\
\hline 24.9 & 299 & أوفق بشدة \\
\hline 22.1 & 265 & أو افق \\
\hline 15.4 & 185 & لارأي \\
\hline 18 & 216 & لا أو افق \\
\hline 19.6 & 235 & لا أو افق بشدة \\
\hline 100 & 1200 & المجموع \\
\hline
\end{tabular}

يتبين من الجدول (49) أن نسبة (47\%) من عينة الدراسة يو افقون على عبار ات الفرضية الثالثة بينما بلغت نسبة

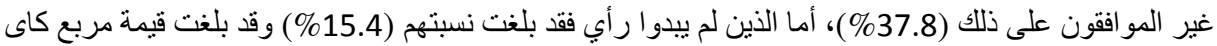

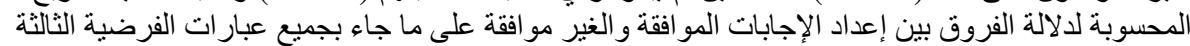

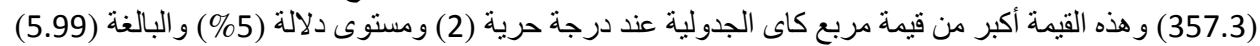

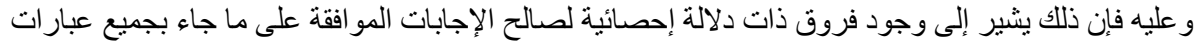

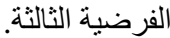

وما تقام يتضح أن فرضية الدراسة الثالثة والتي نصت على أن يوجد أثر الثر ذو دلالة إحصائية عند مستوى (0.05)

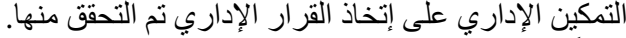
رابعاً: الفرضية الرابعة: يوجد أثر ذو دلالة إحصائية عند مستوى (0.05) التفويض الإداري على الإنى إنخاذ القرار الإداري

ولإثبات هذه الفرضية سيتم أو لاً تقدير الوسيط لجميع عبار ات الفرضية لمعرفة اتجاه عينة الدراسة وفيما يلي الجدول

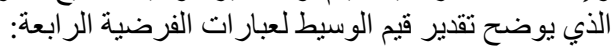
جدول (50). الوسيط لإجابات أفر اد عينة الدراسة على عبار ات الفرضية الر ابعة

\begin{tabular}{|c|c|c|}
\hline التفسير & الوسيط & 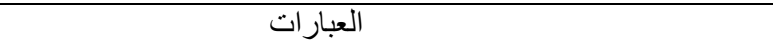 \\
\hline أو افق & 2 & تعتمد الشركة على تفويض الصلاحيات إلى المستويات الإدارية المختلفة \\
\hline 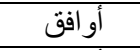 & 2 & هنالك وضوح في توزيع الصلاحيات فى الشركة \\
\hline أو افق & 2 & هنالك وضوح فى نوزيع المسؤوليات فى الثركة \\
\hline أو أفق بشدة & 1 & يتميز توزيع الصلاحيات بالشفافية \\
\hline
\end{tabular}

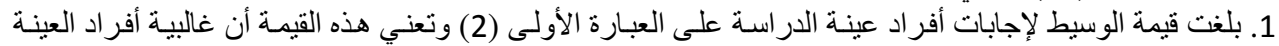

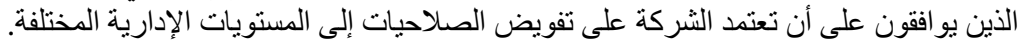

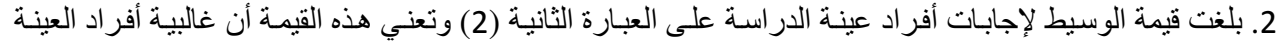

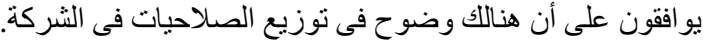

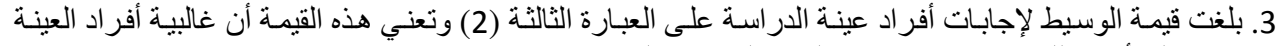

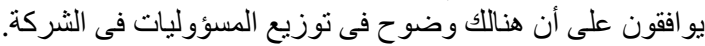

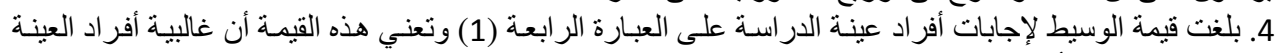
يو افقون بشدة على أن ينميز نوزيع الصناحيات النيات بالثفافية.

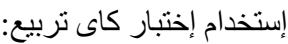

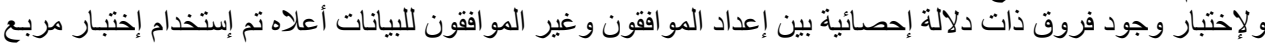

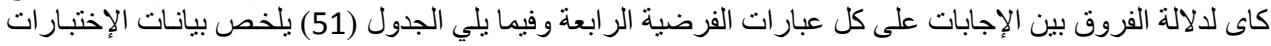

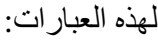


The Effect of strategic management.....

جدول (51). بيانات إختبار مربع كاى لدلالة الفروق لإجابات الفرضية الرابعة

\begin{tabular}{|c|c|c|}
\hline كربعة & الحرية & العبار ات \\
\hline 59.16 & 2 & تعتمد الثركة على تفويض الصلاحيات إلى المستويات الإدارية المختلفة \\
\hline 37.8 & 2 & هنالك وضوح فى توزيع الصلاحيات فى الثركة \\
\hline 67 & 3 & هناللك وضوح فى توزيع المسئوليات فى الشركة \\
\hline 97.3 & 2 & يتميز توزيع الصلاحيات بالثفافية \\
\hline
\end{tabular}

1. بلغت قيمة مربع كاى المحسوبة لدلالة الفروف بين أفر اد عينة الدر اسـة للعبـارة الأولى (59.16) و هذه القيمـة أكبر

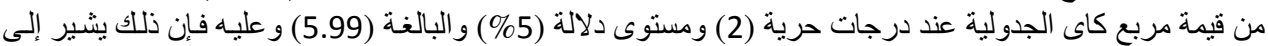

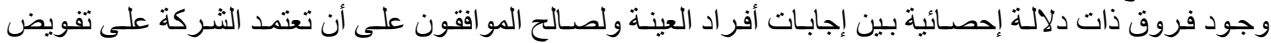

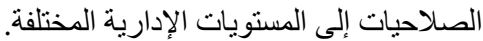

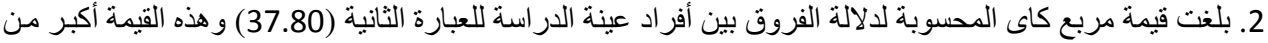

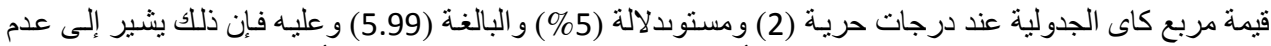

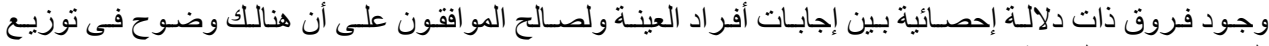

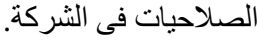

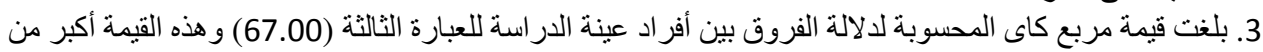

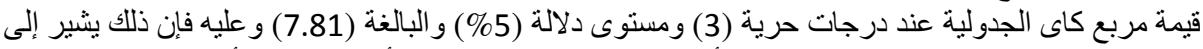

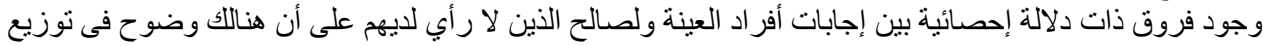

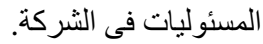

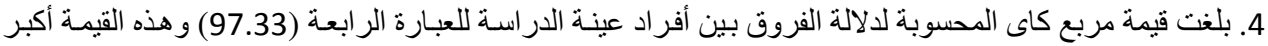

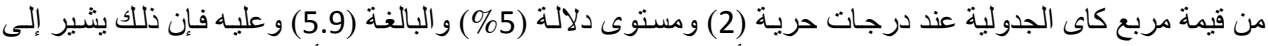

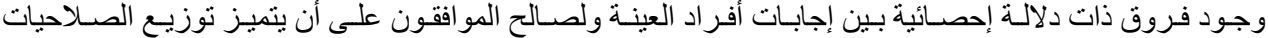
بالثفافية.

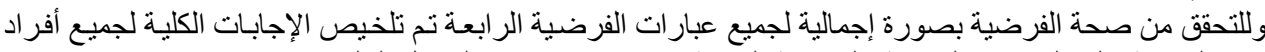

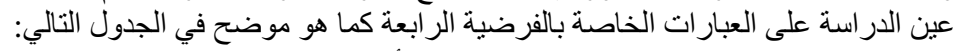

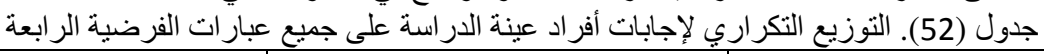

\begin{tabular}{|c|c|c|}
\hline$\%$ & العدد & الإجابة \\
\hline 26 & 307 & أوفق بشدة \\
\hline 23.5 & 282 & أو افق \\
\hline 12.4 & 149 & لا رأي \\
\hline 17.7 & 212 & لا أو افق \\
\hline 20.8 & 250 & لا أو افق بشدة \\
\hline 100 & 1200 & المجموع \\
\hline
\end{tabular}

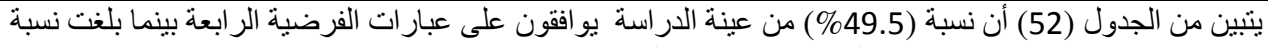

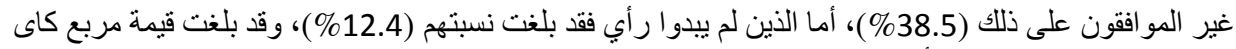

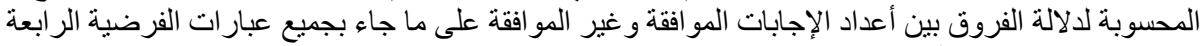

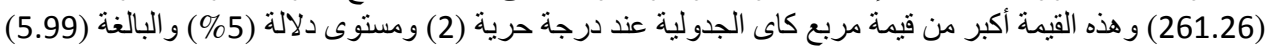

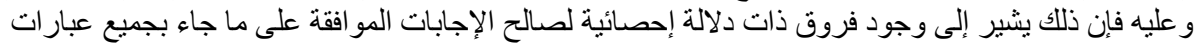
الفرضية الر ابعة.

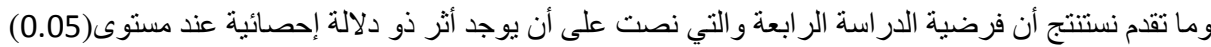

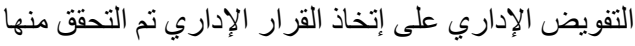


خامساً: الفرضية الخامسة: يوجد أثر ذو دلالة إحصائية عند مستوى (0.05) المشاركة في إتخاذ القرارات على إتخاذ القرار الإداري.

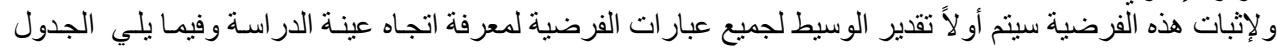

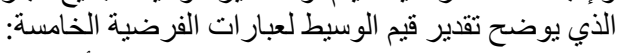
جدول (53). الوسيط لإجابات أفراد عينة الدر اسة على الفيلى عبار ات الفرضية الخامسة

\begin{tabular}{|c|c|c|}
\hline التفبير & الوسيط & 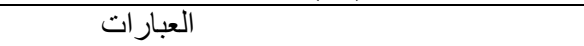 \\
\hline 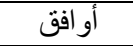 & 2 & لا يوجد تدخل للرؤساء فى عمل المرؤسين \\
\hline 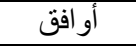 & 2 & تو افر للمعلومات المتو افرة لصنع القرار الاداري \\
\hline 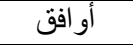 & 2 & يوجد نظام واضح لتقسيم العمل بين الموظفين \\
\hline أو افق بشدة & 1 & لا تدخل العلاقات الثخصية فى صنع القرار الاداري \\
\hline 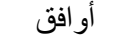 & 2 & اهتمام الادارة بملاحظات الموظفين أدى لتحسين الاداء \\
\hline
\end{tabular}

يتبين من الجدول (53) ما يلي:

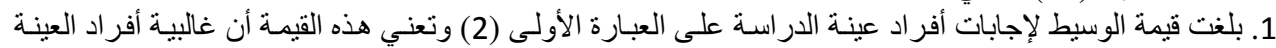

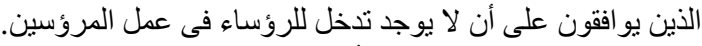

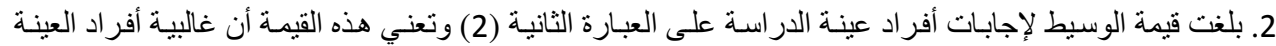

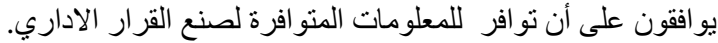

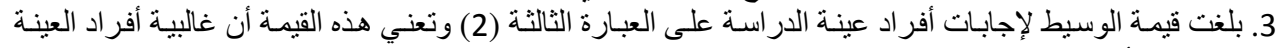

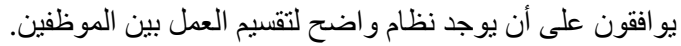

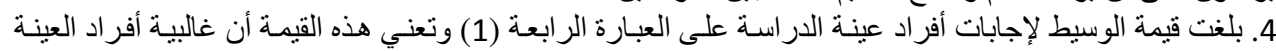

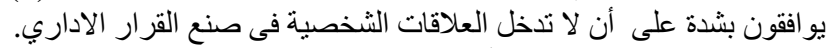

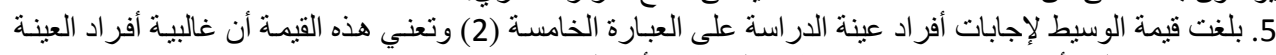

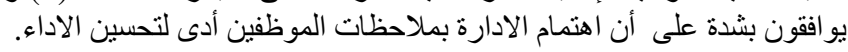

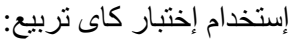

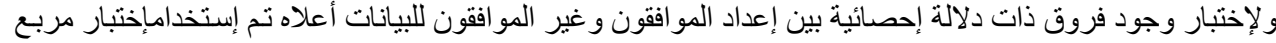

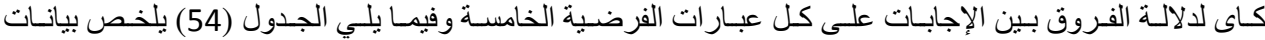
الإختبار ات لهذه العبار ات: جدول (54). بيانات إختبار مربع كاى لدلالة الفروق لإجابات الفرضية الخامسة

\begin{tabular}{|c|c|c|}
\hline قيمة مربع & الحرجة & 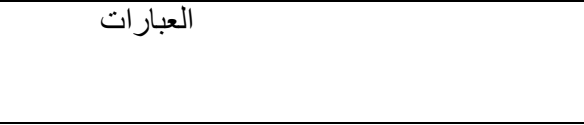 \\
\hline 62.2 & 2 & لا يوجد تدخل للرؤساء فى عمل المرؤسين \\
\hline 18.5 & 2 & تو افر للمعلومات المتو افرة لصنع القرار الاداري \\
\hline 84.6 & 3 & بوجد نظام و اضح لتقسيم العمل بين الموظفين \\
\hline 81.4 & 2 & لا تدخل العلاقات الثخصية فى صنع القرار الاداري \\
\hline 95.2 & 2 & اهتمام الادارة بملاحظات الموظفين أدى لتحسين الاداء \\
\hline
\end{tabular}

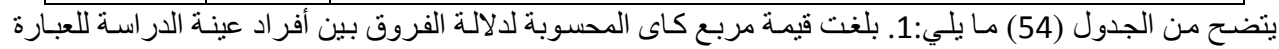

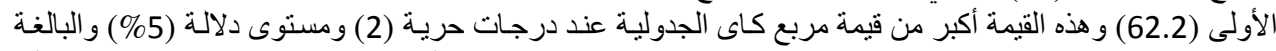

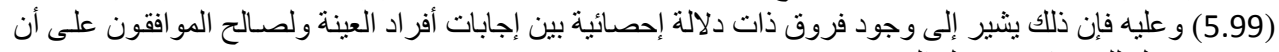

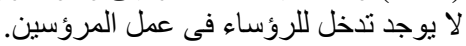

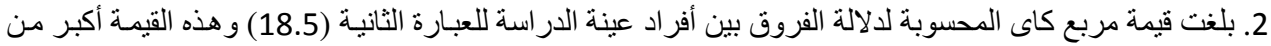

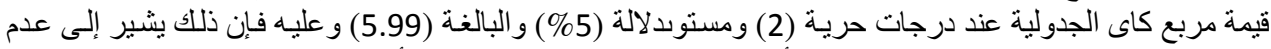

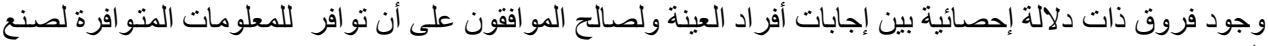
القرار الاداري. 
The Effect of strategic management.....

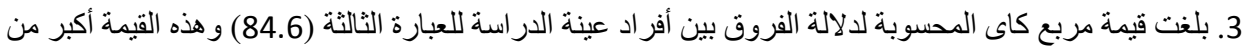

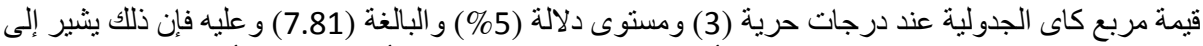

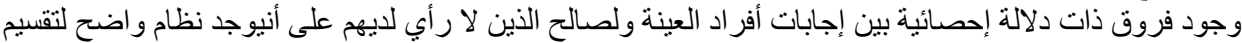

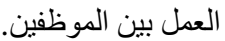

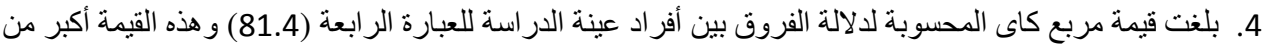

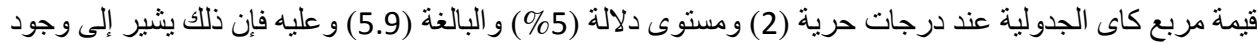
فروق ذات دلالة إحصائية بين إجابات أفراد العينة ولصالح المو افقون على أن لا تدخل العلاقات العات الثخصية في صنع

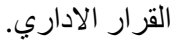

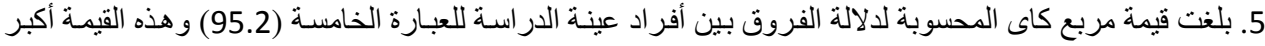

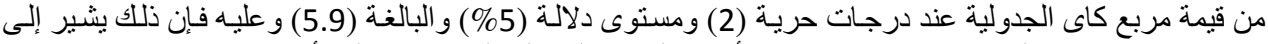

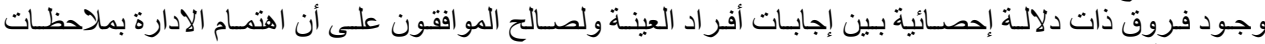

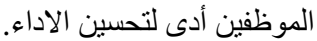
وللتحقق من صحة الفرضية بصورة إجمالية لجميع عبار ات الفرضية الراب ابعة تم تلخيص الإجابات الكلية لجميع أفراد

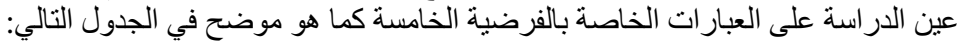

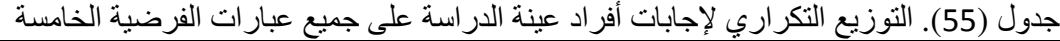

\begin{tabular}{|c|c|c|}
\hline$\%$ & العدد & الإجابة \\
\hline 24.8 & 372 & أوفق بثدة \\
\hline 25 & 378 & أو افق \\
\hline 14.1 & 212 & لار رأي \\
\hline 14.2 & 213 & لا أو افق \\
\hline 21.7 & 325 & لا أو افق بشدة \\
\hline 100 & 1500 & المجموع \\
\hline
\end{tabular}

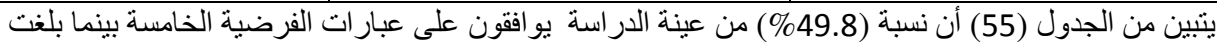

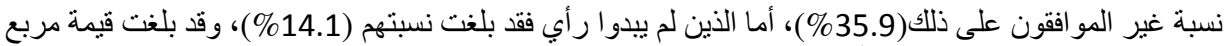

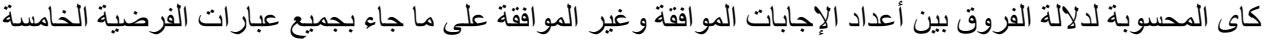

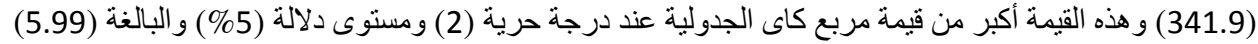

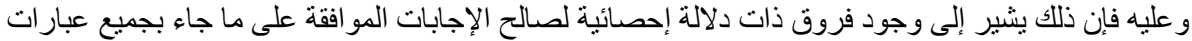
الفرضية الخامسة.

وما تقدم نستنتج أن فرضية الدراسة الخامسة والتي نصت على أنى النقا يوجد أثر ذو دلالة إحصائية عند مستوى(0.05)

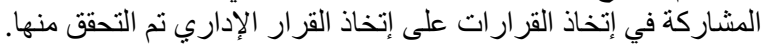

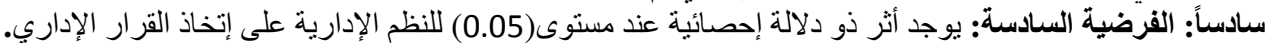

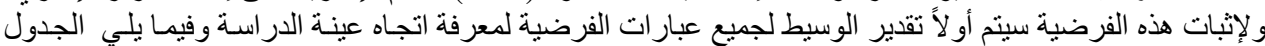
الذي يوضح تقدير قيم الوسيط لعبار ات الفرضية الإنية السادسة: جدول (56). الوسيط لإجابات أفر اد عينة الدراسة على عبار ات الفرضية السادسة

\begin{tabular}{|c|c|c|}
\hline التفسير & الوسيط & العبارا \\
\hline أو افق & 2 & توجد نظم تحكم العمل بالثركة \\
\hline أو افق & 2 & لدى الثركة قو انين رادعة \\
\hline أو افق & 2 & يلتزم الموظفون بالنظم مما حسن الاداء \\
\hline أو افق بشدة & 1 & القو انيين الموجو دة بالشركة و اضحة \\
\hline
\end{tabular}

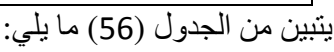
1. بلغت قيمة الوسيط لإجابات أفر اد عينـة الدراسة على العبارة الأولى (2) وتعني هذه القيمة أن غالبية أفر اد العينة

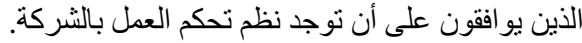

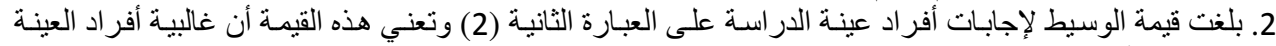
يو افقون على أن لدى الثركة قو انيين رادعة. 
Journal of Social Sciences (COES\&RJ-JSS), 7(4), pp.303-335

3. بلغت قيمـة الوسبط لإجابـات أفر اد عينـة الدر اسـة على العبـارة الثالثة (2) وتعني هذه القيمـة أن غالبيـة أفر اد العينـة

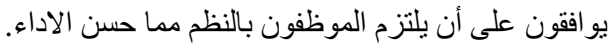

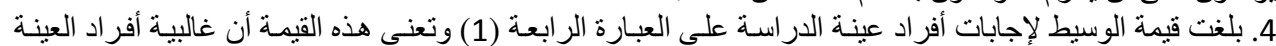

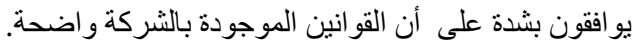

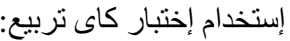

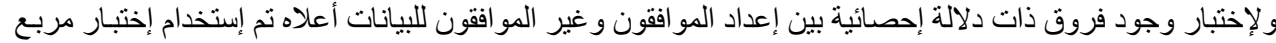

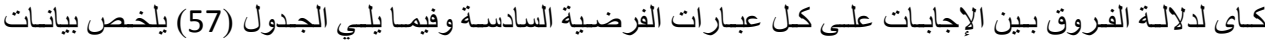

جدول (57). بيانات إختبار مربع كاى لدلالة الفروق لإجابات الفرضية السادسة الإختبار ات للهذه العبار ات: الاتروف:

\begin{tabular}{|c|c|c|}
\hline قيمة مربع & الحرية & العبار ات \\
\hline 56.3 & 2 & توجد نظم تحكم العمل بالشركة \\
\hline 48.6 & 2 & لدى الشركة قو انيين رادعة \\
\hline 63.9 & 3 & يلتزم الموظفون بالنظم مما حسن الاداء \\
\hline 24.3 & 2 & القو انين الموجودة بالثركة و اضحة \\
\hline
\end{tabular}

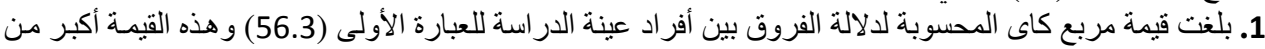

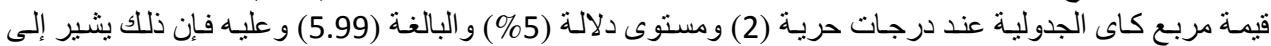

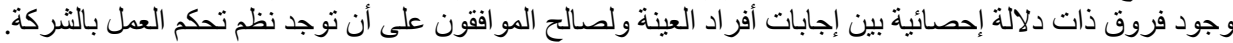

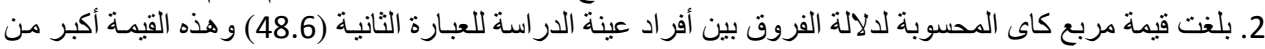

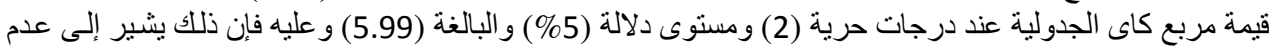

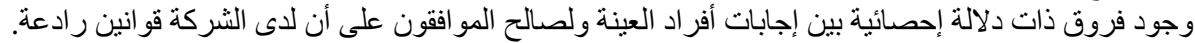

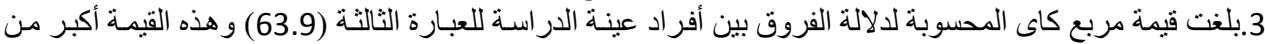

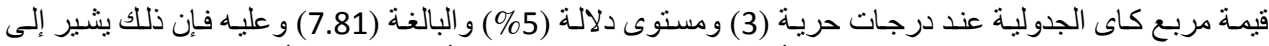
وجود فروق ذات دلالة إحصائية بين إجابات أفر اد العينة ولصـالح الذين لا رأي لديهم على أن أن يلتزم الموظفون بـالنظم مما حسن الاداء.

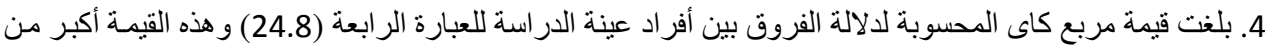

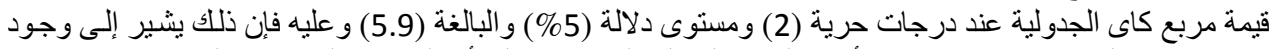

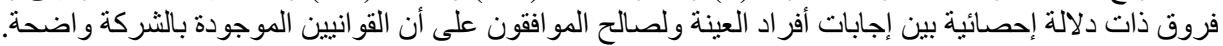

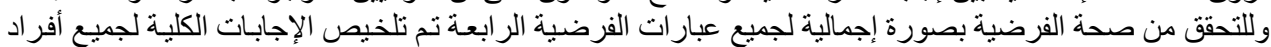

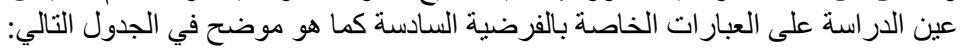

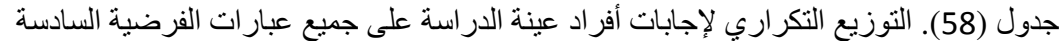

\begin{tabular}{|c|c|c|}
\hline$\%$ & العدد & الإجابة \\
\hline 29.3 & 352 & أوفق بشدة \\
\hline 21.1 & 253 & أو افق \\
\hline 15.8 & 190 & لا رأي \\
\hline 8.9 & 107 & لا أو افق \\
\hline 24.8 & 298 & لا أوافق بشدة \\
\hline 100 & 1200 & المجموع \\
\hline
\end{tabular}

يتبين من الجدول (58) أن نسبة (50.4\%) من عينة الدر اسة يو افقون على عبار ات الفرضية السادسة بينما بلغت نسبة

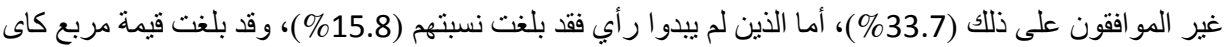
المحسوبة لدلالة الفروق بين أعداد الإجابات المو افقة و غير الموافقة الفئ على ما جاء بجميع عبار ات الفرات الفية الفية السادسة

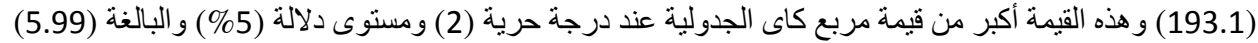

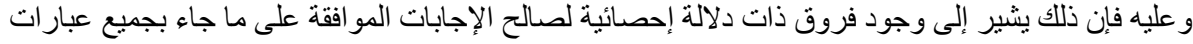


The Effect of strategic management.....

الفرضية السادسة. وما تقدم نستتتج أن فرضية الدر اسة السادسة والتي نصت على أن يوجد أثر ذو دلالة إحصائية عند

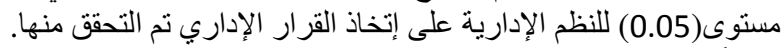
سابعاً: الفرضية السابعة: يوجد أثر ذو دلإلة إحصائية عند مستوى (0.05) جودة القرارية تلإدات الإدارية على إتخاذ القرار الإداري

و لإثبات هذه الفرضية سيتم أو لاً تقدير الوسيط لجميع عبار ات الفرضية لمعرفة اتجـاه عينـة الدراسـة وفيمـا يلي الجدول

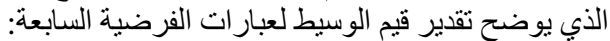
جدول (59). الوسيط لإجابات أفراد عينة الدراسة الفرة على عبار ات الفرضية السابعة

\begin{tabular}{|c|c|c|}
\hline التفسير & الوسيط & العبار ات \\
\hline 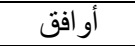 & 2 & القر ار ات الإدارية تتم عن طريق المشاركة \\
\hline أو افق & 2 & القرار ات الإدارية تدعم أهداف المنظمة \\
\hline 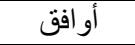 & 2 & القرار ات الإدارية تركز على مصلحة العمل \\
\hline أو افق بشدة & 1 & القر ار ات الإدارية تركز على مصلحة الموظفين \\
\hline 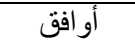 & 2 & القر ار ات الإدارية بالثركة صائبة \\
\hline أو افق بشدة & 1 & القرار ات الإدارية عادلة \\
\hline أو افق بشدة & 1 & القرار ات الإدارية تتم في اطار النظم المعمول بها \\
\hline
\end{tabular}

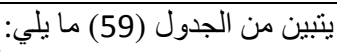

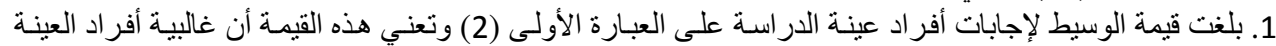

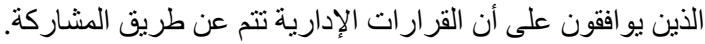

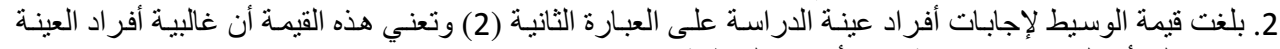

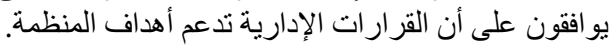

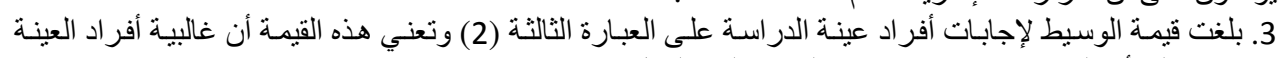

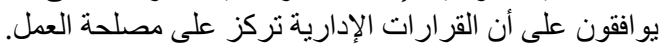

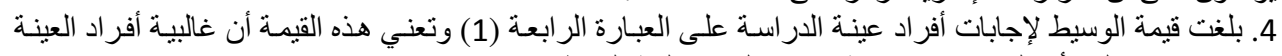

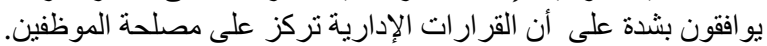

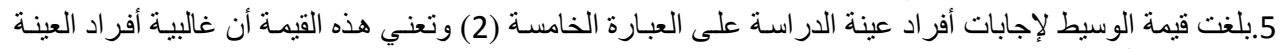

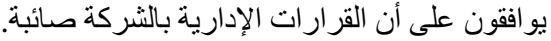

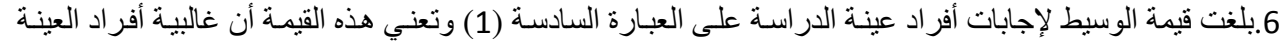
يو افقون بشدة على أن القرار ات الإدارية عادلة.

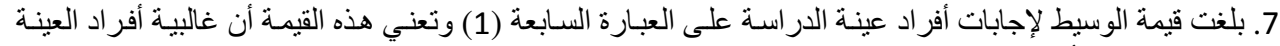

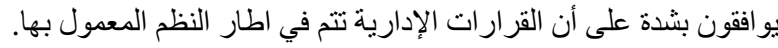

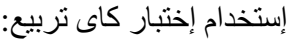

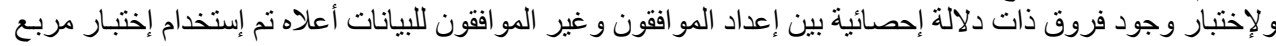

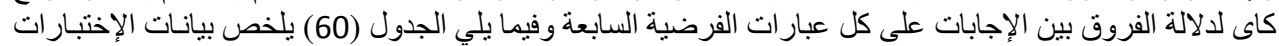
جدول (60). بيانات إختبار مربع كاى لدلالة الفروق لإجابات الفرضية السابعة لهذه العبار ات: الالة التزو

\begin{tabular}{|c|c|c|}
\hline قيمة مربع & الحرية & العبار ات \\
\hline 52.2 & 2 & القر ار ات الإدارية تتم عن طريق المشاركة \\
\hline 63.1 & 2 & القرارات الإدارية تدعم أهداف المنظمة \\
\hline 45.1 & 3 & القرارات الإدارية تركز على مصلحة العمل \\
\hline 33.4 & 2 & القر ار ات الإدارية تركز على مصلحة الموظفين \\
\hline 56.4 & 2 & القر ار ات الإدارية بالثركة صـائبة \\
\hline 65.2 & 2 & القر ارات الإدارية عادلة \\
\hline 43.5 & 2 & القرارات الإدارية تتم في اطار النظم المعدول بها \\
\hline
\end{tabular}


يتضح من الجدول (60) ما يلي:

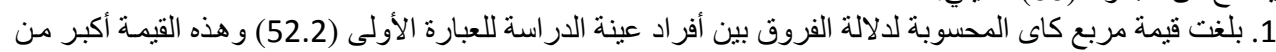

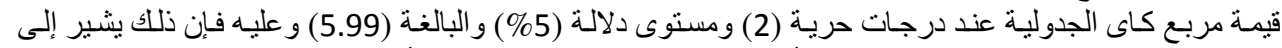
وجود فروق ذات دلالة إحصائية بين إجابات أفر اد العينة ولصالح المو افقون على أن القرارات الإدارية تتم عن طريق المشاركة.

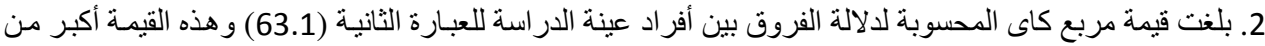

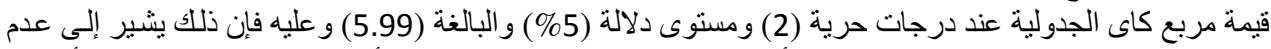

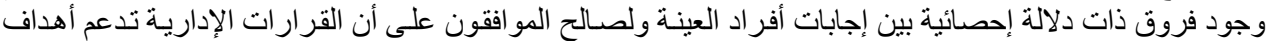

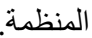

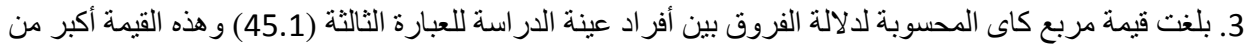

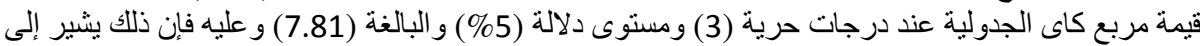

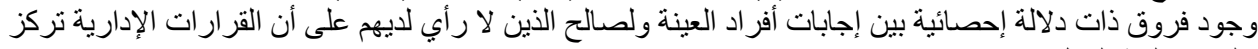

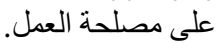

4. بلغت قيمة مربع كاى المحسوبة لدلالة الفروق بين أفراد عينة الدراسة للعبارة الر ابعة (33.4) و هذه القيمة الكية أكبر من

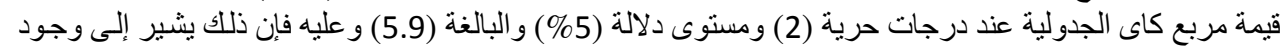

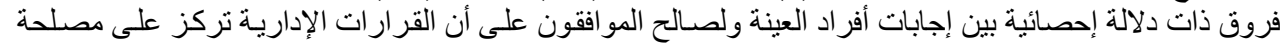

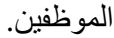

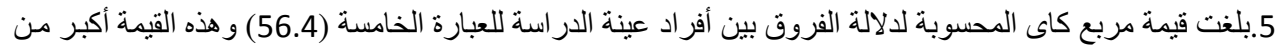

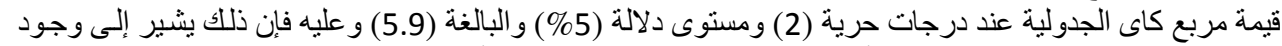

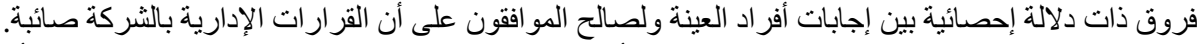

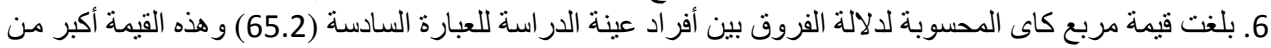

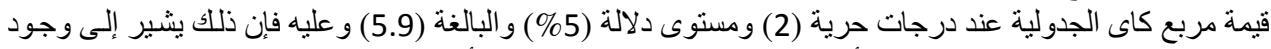

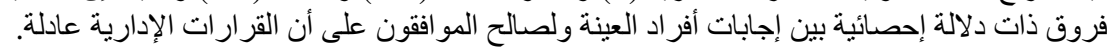

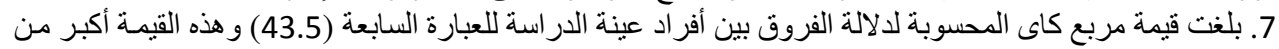

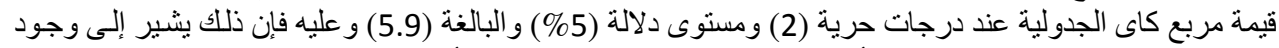

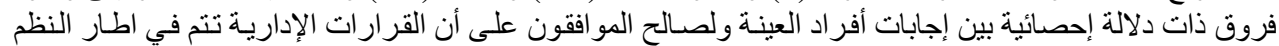
المعمول بها.

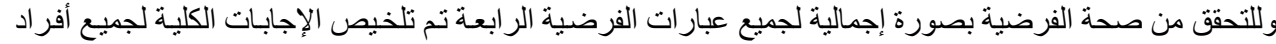

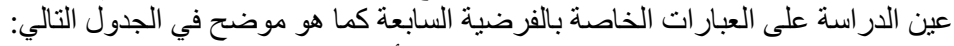
جدول (61). التوزيع التكراري لإجابات أفراد عينة الدراسة على جميع عبار التهات الفرضية السابعة

\begin{tabular}{|c|c|c|}
\hline$\%$ & العدد & الإجابة \\
\hline 29.1 & 611 & أوفق بشدة \\
\hline 18.1 & 381 & أو افق \\
\hline 14.4 & 303 & لارأي \\
\hline 15.2 & 320 & لا أو افق \\
\hline 23.1 & 485 & لا أو افق بشدة \\
\hline 100 & 2100 & المجموع \\
\hline
\end{tabular}

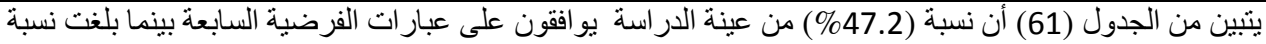

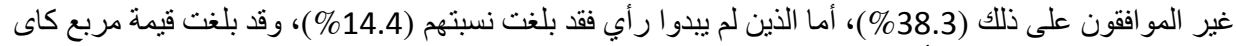

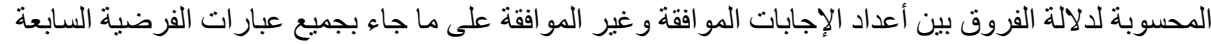

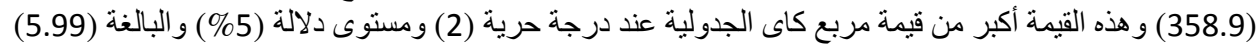

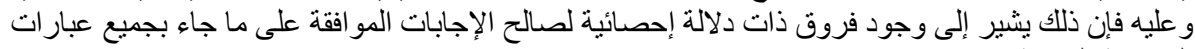
الفرضية السابعة. وما تقدم نستتنج أن فرضية الدراسة السابعة والتي نصت على أن يوجد أثر ذو دلالة إحصائية عند مستوى(0.05) جودة القرارات الإدارية على إتخاذ القرار الإداري تم التحقق منها. 


\section{الأنــــــاتمة \\ أولاً: النتائج}

1. عملية التفويض الإداري داخل شركة الفوسفات الأردنية ساعدت في تحقيق الكفاءة وحسن الأداء.

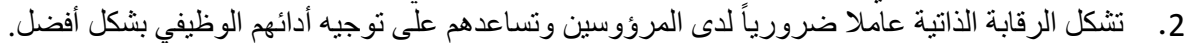

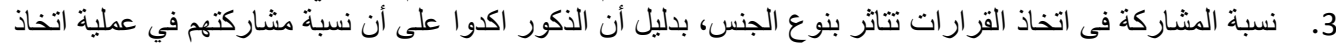

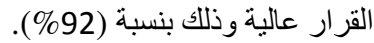

4. تعمل إدارة الثركة على تطوير الهيكل التنظيمي بصورة مستمرة لموكبة التطورات الحديثة لدعم العمل وتحسين

5. ساعدت الأنظمة والتعليمات على تطوير القرار الإداري بشركة الفوسفات الأردنية.

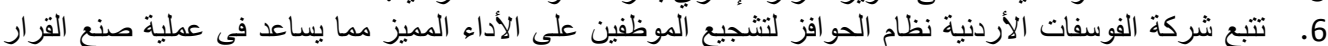
السليم بنسبة (185\%).

7. يتميز توزيع الصلاحيات بشركة الفوسفات الأردنية بالثفافية مما ساعد في اتخاذ القرار الاداري السليح.

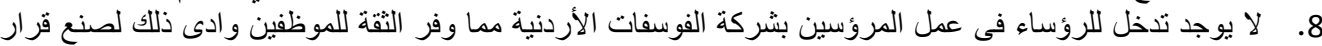

سليم.

9. لا تدخل العلاقات الثخصية فى صنع القرار الاداري بشركة الفوسفات الأردنية مما أتاح للموظفين فرصة المشاركة

في صنع القرار بأريحيه.

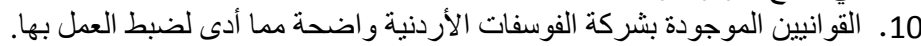

11. القرارات الإدارية بشركة الفوسفات الأردنية تركز على مصلحة الفينة الموظفين مما شجعهم على الاداء التميز وذلك بنسبة

12. القرارات الإدارية بشركة الفوسفات الأردنية تتم في اطار النظم المعمول به مما جعلها سليمة.

ثانياً: التوصيات الإدات

1. الاهتمام بإز الة المعوقات التهى تحد من مشاركة الموظفين بشركة الفوسفات الأردنية في صنع القرار الإداري.

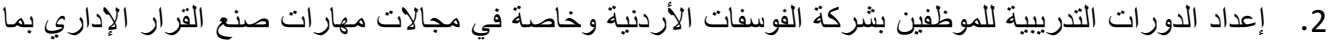

تيزيد الوعي بها.

3. تقديم الدعم المعنوي للموظفين بشركة الفوسفات الإردنية على المشاركة في صنع القرار.

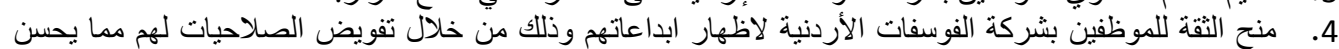

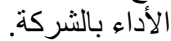

5. مر اجعة القو انين و الاجر اءعات المنظمة للعمل للملائمة مع مستجدات العمل.

6. إشر اك كل الموظفين في عملية صنع القر ار الإداري لمعرفة معوقات الإت الأداء بشركة الفوسفات الأردنية.

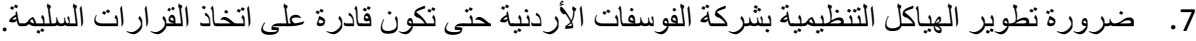

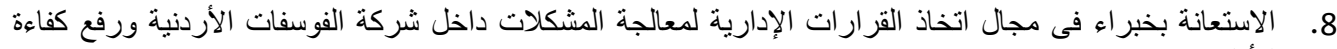

الأداء.

9. ضرورة مر اعاة العو امل الداخلية والخارجية بما لا يؤثر سلباً على عملية صنع القرار الإداري.

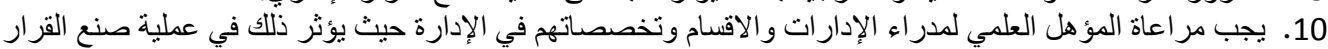

الإداري.

11. يجب مر اعاة سنوات الخبرة لمدراء الإدارات والاقسام ومؤهلاتهم العلمية في الإدارة حيث يؤثر ذلك في عملية صنع

القرار الإداري.

\section{References}

Abualoush, S., Masa'deh, R., Bataineh, K., \& Alrowwad, A. (2018). The Role of Knowledge Management Process and Intellectual Capital as Intermediary Variables between Knowledge Management Infrastructure and Organization Performance. Interdisciplinary Journal of Information, Knowledge, and Management, 13, 279-309. 
Alenezi, H., Tarhini, A., Alalwan, A., \& Al-Qirim, N. (2017). Factors Affecting the Adoption of E-Government in Kuwait: A Qualitative Study. Electronic Journal of e-Government, 15(2), 84-102.

Alkandari, A., Masa'deh, R., \& Al-Lozi, M. (2017). Knowledge Management and its Role on Organizational Crisis Management: A Literature Review. Journal of Social Sciences (COES\&RJ-JSS), 6(4), 833-850.

AL-Lozi, M. (2002). Total Quality Management in the Civil Service institutions in Jordan. Mu'tah: Humanities and Social Sciences Series, 18(4), 151-185.

AlHarrasi, J., \& AL-Lozi, M. (2015). The Role of Innovation Management and Technological Innovation on Organizational Effectiveness. 4th Scientific \& Research Conference on New Trends in Business, Management and Social Sciences (COES\&RJTK15/1), Istanbul, Turkey.

AlHarrasi, J., \& AL-Lozi, M. (2016). The Role of Innovation Management and Technological Innovation on Organizational Effectiveness: A Theoretical Model. Journal of Social Sciences (COES\&RJ-JSS), 5(1), 80-95.

AlHrassi, J., Al-Lozi, M., \& Irtaimeh, H. (2016). The Impact of Management Innovation and Technological Innovation on Organizational Effectiveness: An Empirical Study from Managerial Staff Perspective in Sultan Qaboos University. Journal of Social Sciences (COES\&RJ-JSS), 5(3), 309-339.

Almajali, D., Masa'deh, R., \& Al-Lozi, M. (2016). Determinants of the Actual Use of ELearning Systems: An Empirical Study on Zarqa University in Jordan. Journal of Social Sciences (COES\&RJ-JSS), 5(2), 172-200.

AL-Syaidh, N., Al- Lozi, M., \& AlHarrasi, J. (2016). Transformational Leadership and its Role on the Effectiveness of Employees' Behavior: A Theoretical Study. Journal of Business \& Management (COES\&RJ-JBM), 4(1), 14-35.

AL-Syaidh, N., Masa'deh, R., \& Al-Zu'bi, Z. (2014). Transformational Leadership and its Impact on the Effectiveness of Employees' Behavior in the Public and Private Jordanian Hospitals. Jordan Journal of Business Administration, 11(1), 23-57.

Ammari, G., Alkurdi, B., Alshurideh, A., \& Alrowwad, A. (2017). Investigating the Impact of Communication Satisfaction on Organizational Commitment: A Practical Approach to Increase Employees' Loyalty. International Journal of Marketing Studies, 9(2), 113-133.

Arnold, E., \& Pulich, M. (2003). Managing Effectively in the Downsized Organization. Health Care Manager, 22(1), 56-62. 
Darawsheh, S., ALshaar, A., \& AL-Lozi, M. (2016). The Degree of Heads of Departments at the University of Dammam to Practice Transformational Leadership style from the Point of View of the Faculty Members. Journal of Social Sciences (COES\&RJ-JSS), 5(1), 56-79.

Khalayleh, W., Masa'deh, R., \& Al-Lozi, M. (2017). Administrative Empowerment and its Role on the Work Teams Performance: A Literature Review. Journal of Social Sciences (COES\&RJ-JSS), 6(4), 851-868.

Khwaldeh, S., Al-Hadid, I., Masa'deh, R., \& Alrowwad, A. (2017). The Association between E-Services Web Portals Information Quality and ICT Competence in the Jordanian Universities. Asian Social Science, 13(3), 156-169.

Masa'deh, R., Alrowwad, A., Alkhalafat, F., Obeidat, B., \& Abualoush, S. (2018). The Role of Corporate Social Responsibility in Enhancing Firm Performance from the Perspective of IT Employees in Jordanian Banking Sector: The Mediating Effect of Transformational Leadership. Modern Applied Science, 12(7), 1-26.

Masa'deh, R., Obeidat, B., Zyod, D., \& Gharaibeh, A. (2015). The Associations among Transformational Leadership, Transactional Leadership, Knowledge Sharing, Job Performance, and Firm Performance: A Theoretical Model. Journal of Social Sciences (COES\&RJ-JSS), 4(2), 848-866.

Mikkawi, B., \& Al-Lozi, M. (2017). The Impact of Knowledge Management Infrastructure on Academic Staff Effectiveness: An Empirical Study at The University of Jordan. Jordan Journal of Business Administration, 13(1), 95-127.

Obeidat, O., Tarhini, A., \& Aqqad, N. (2017). The Impact of Intellectual Capital on Innovation via the Mediating Role of Knowledge Management: A Structural Equation Modeling Approach. International Journal of Knowledge Management Studies, 8(3/4), 273-298.

Tarhini, A., Mgbemena, C., \& Trab, MSA. (2015). User Adoption of Online Banking in Nigeria: A Qualitative Study. Journal of Internet Banking and Commerce, 20(3), 1-8.

Yassien, E., \& Mufleh, M. (2017). The Impact of ERP System's Usability on Enterprise Resource Planning Project Implementation Success via the Mediating Role of User Satisfaction. Journal of Management Research, 9(3), 49-71. 